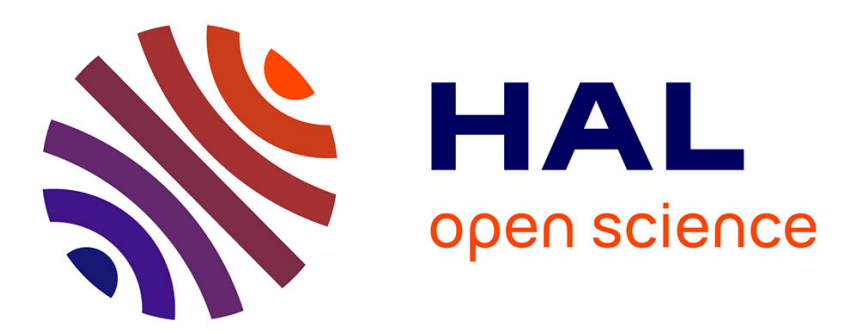

\title{
A geochemical and geophysical investigation of the hydrothermal complex of Masaya volcano, Nicaragua
} Guillaume Mauri, Glyn Williams-Jones, Ginette Saracco, Jeffrey M Zurek

\section{To cite this version:}

Guillaume Mauri, Glyn Williams-Jones, Ginette Saracco, Jeffrey M Zurek. A geochemical and geophysical investigation of the hydrothermal complex of Masaya volcano, Nicaragua. Journal of Volcanology and Geothermal Research, 2012, 227-228, pp.15-31. 10.1016/j.jvolgeores.2012.02.003 . hal03100186

\section{HAL Id: hal-03100186 \\ https://hal.science/hal-03100186}

Submitted on 19 Jan 2021

HAL is a multi-disciplinary open access archive for the deposit and dissemination of scientific research documents, whether they are published or not. The documents may come from teaching and research institutions in France or abroad, or from public or private research centers.
L'archive ouverte pluridisciplinaire HAL, est destinée au dépôt et à la diffusion de documents scientifiques de niveau recherche, publiés ou non, émanant des établissements d'enseignement et de recherche français ou étrangers, des laboratoires publics ou privés. 
A geochemical and geophysical investigation of the hydrothermal complex of Masaya volcano, Nicaragua

Guillaume Mauri a,*, Glyn Williams-Jones a, Ginette Saracco ${ }^{\text {b }}$, Jeffrey M. Zurek ${ }^{\text {a }}$

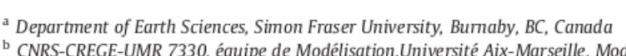

'CNRS-CREGE-UMR 7330, équipe de Modélisation,Université Aix-Marseille, Modélisation, Europole de IArbois, BP 80, 13545 Aix-en-Provence cedex 4, France

A B S TRACT

Masaya volcano, Nicaragua, is a persistently active volcano characterized by continuous passive degassing for more than 150 years through the open vent of Santiago crater. This study applies self-potential, soil $\mathrm{CO}_{2}$ and sround temperature measuthe volcano. The diffuse degassing areas are organized in a semi-circusar patterand coincide with several visible and inferred surface volcanic structures (cones, fissure vents) and likely consist of a network of buried faults and dykes that respectively channel uprising flow and act as barrier to gravitational groundwater flow. Water depths have been estimated by multi-scale wavelet tomography of the self-potential data using wavelets from the Poisson kernel family. Compared to previous water flow models, our water depth estimates are shallower and mimic the topography, typically less than $150 \mathrm{~m}$ below the surface. Between 2006 and 2010, the depths of rising fluids along the survey profiles remained stable suggesting that hydrothermal activity is in a steady state. This stable activity correlates well with the conWhen compared to previous strues a degasing

tures have an important effect on the path that shallow groundwater follows to reach the Laguna de Mstrucin the eastern part of the caldera. The hydrogeological system is therefore more complex than previously published models and our new structural model implies that the flow of shallow groundwater must bypass the intrusions to reach the Laguna de Masaya. Furthermore, these diffuse degassing structures show clear evidence of activity and must be connected to a shallow magmatic or hydrothermal reservoir beneath the caldera. As such, the heat budget for Masaya must be significantly larger than previously estimated.

Keywords

Masaya, Hydrothermal, Self-potential, Wavelet, Groundwater, Volcano

\section{Introduction}

Masaya volcano, Nicaragua $\left(11.984^{\circ} \mathrm{N}, 86.161^{\circ} \mathrm{W}, 635 \mathrm{~m}\right)$, is a basaltic shield system consisting of a summit caldera $(\sim 11.5 \times 6 \mathrm{~km})$ hosting numerous cinder cones, pit craters and fissure vents (McBirney, 1956; Williams, 1983b; Rymer et al., 1998; Acocella, 2007; Harris, 2009) (Fig. 1). The summit caldera is the result of several collapse events (McBirney, 1956; Crenshaw et al., 1982), which are Williams, 1983a; Walker et al., 1993). Since the pioneering work of McBirney (1956), several studies have supported the hypothesis of structural limits controlling the volcanic vent distribution (cinder cones and fissure vents) within the caldera (Williams, 1983a; Maciejewski, 1998), however, different models have been suggested to explain this distribution. Based on field observations, it appea s that three of the fissure vents (e.g., the 1772 fissure vent; Fig. 1) * Corresponding author at: Centre for Hydrogeology and Geothermics-CHYN, Uni-
versité de Neuchâtel, Neuchâtel, Switzerland. have a similar orientation to the main regional Cofradrias fault $\left(\mathrm{N} 5^{\circ} \mathrm{E}\right)$ (Williams, 1983a). Other volcanic structures are oriented differently, such as Masaya cone $\left(\mathrm{N} 70^{\circ} \mathrm{E}\right)$, Nindiri cone $\left(\mathrm{N} 54^{\circ} \mathrm{E}\right)$ and San Pedro fault $\left(\mathrm{N} 48^{\circ} \mathrm{E}\right)$, which suggests a more complex structural influence on the shallow magmatic system (Fig. 1). Field observations suggest that the San Pedro fault (Fig. 2b) is in fact a fissure vent cutting through the west flank of Nindiri cone, starting at the top of San Pedro crater and stopping near Cerro Montozo cone (Fig. 1). On a smaller scale, Masaya and Nindiri cones show signs of collapse with the formation of pit craters (Santiago, San Pedro and San Fernando craters) and subsidence of Nindiri lava lake. Signs of normal faulting are present on the crater walls of Santiago, San Pedro and San Fernando craters (Rymer et al., 1998; Roche et al., 2001; Harris, 2009). Thus, at least in the south part of the caldera, fissure vents and pit craters may be connected at depth by both dykes and faults to a shallow magma chamber. In addition, a normal fault plane (NE-SW strike) associated with fumarolic activity, has been characterized by a previous geophysical study (magnetism and self-potential) across Comalito cone and the fissure vent on the north side of Masaya cone (Pearson, 2010). Farlier geophysical studies (Bouguer gravity mapping), aimed 


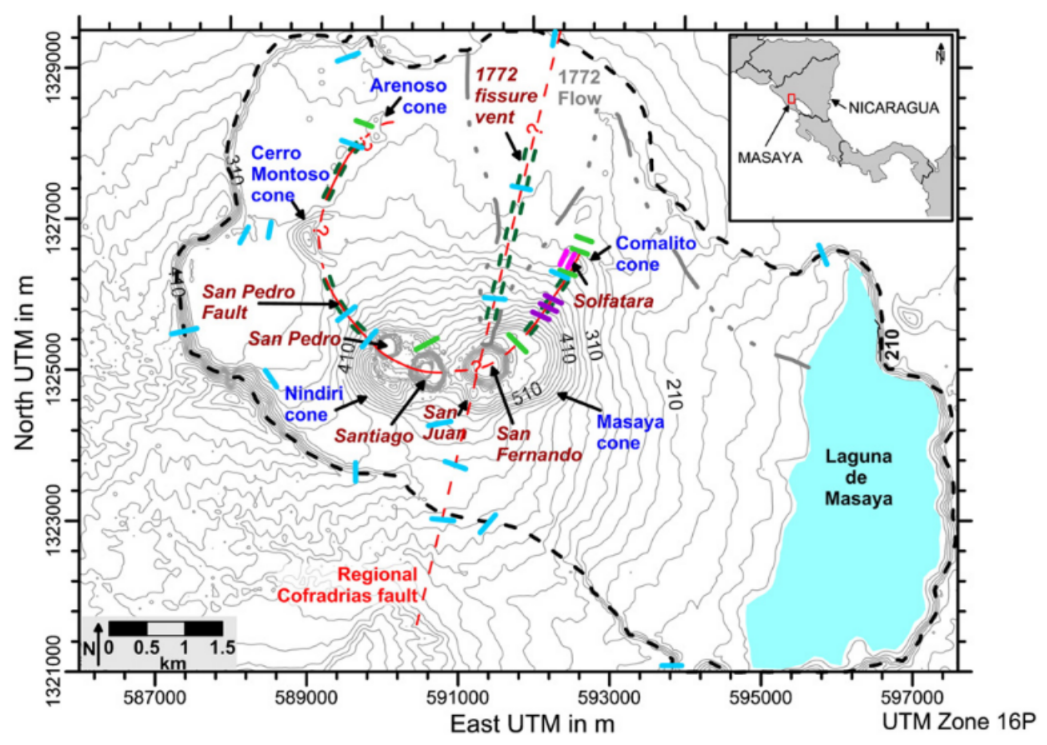

Fig. 1. Masaya caldera, Nicaragua with the post-caldera volcanic cones in blue. The crater names and ground structures are in red. The dark green dashed lines represent the fissure vent structures. Solid red lines are the inferred structure (Crenshaw et al., 1982; Harris, 2009) while the red dashed lines represent hypothetica sus The black dashed line is the inferred limit of the caldera. The grey dashed line represents the margins of the 1772 lava flow. Approximate location of previously published soil gas
anomalies are represented in light blue (Crenshaw et al., 1982), light green (St-Amand, 1999), pink (Lewicki et al., 2003) and purple (Pearson, 2010). (For interpretation of the references to color in this figure legend, the reader is referred to the web version of this article.)

determining the sources controlling these volcanic structures, were inconclusive due to small density contrasts between the rock formations
and insufficient survey stations (Connor and Williams, 1990; Metaxian,
Maciejewski, 1998). While it is likely that regional faults influence the 1994). One model suggests that the distribution of both fissure vents shallow magmatic system, it is also likely that more local effects, such and cinder cones is controlled by the regional tensional stress associated as depth and shape of a magma chamber, play significant roles in the disto regional faults (Williams, 1983a), while another model suggests that tribution of the volcanic vents.

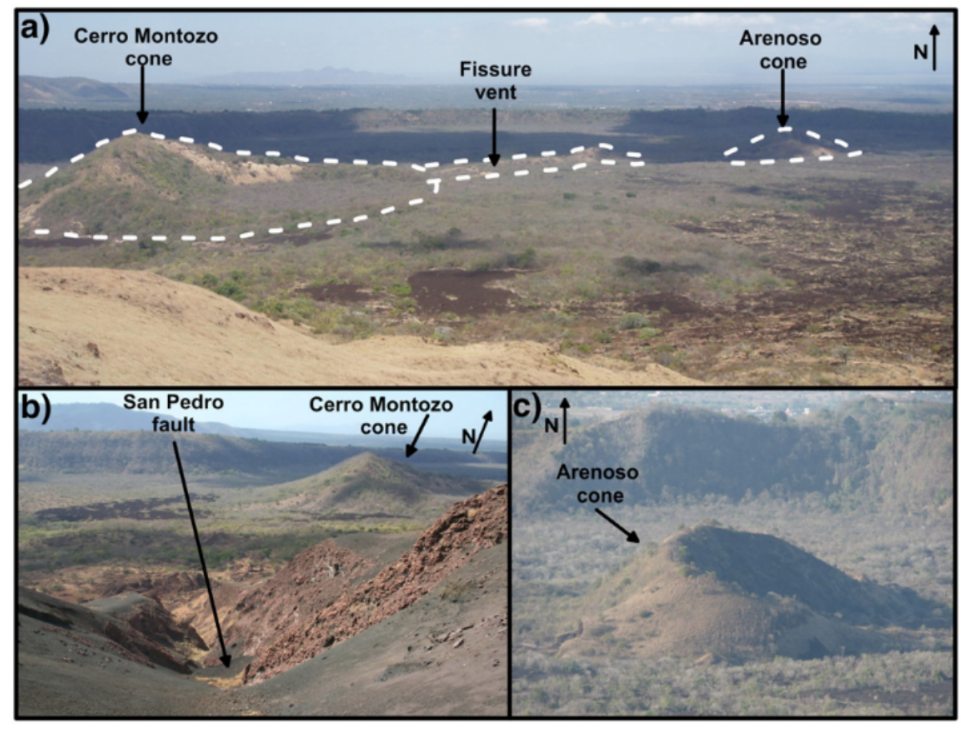


Recent significant volcanic activity (small vent-clearing explosions and continuous degassing) originates solely from Santiago crater withi the Nindiri cone. The presence and frequent renewal of significan amounts of fresh magma near the surface is physically expressed through continuous degassing $\mathrm{SO}_{2}$ flux $>500 \mathrm{~d}$. and variable in-

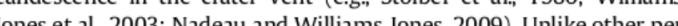
sistenty a tive quent ffusive buptions (eg Kilarea in Hawai, Pitonde la Fouraise a Réunin), since the (1800s. Masaya volcan has had on infreque and volumetrically megligible emissions of juvenile merat The most and volumetrically negligible emissions of juvenile material. The most 1998) and covered a significant part of the north sector of the calder.

Previous studies on gas concentrations and flux $\left(\mathrm{SO}_{2} \mathrm{CO}_{2}\right.$ etc). ravity, deformation and seismicity have highlighted the existence f an extensive magmatic plumbing system at shallow depths open to the atmosphere through Santiago crater (Crenshaw et al 1982; Williams, 1983; Walker and Williams, 1986; Stoiber et al, 1986; Walker et al. 1993: Métaxian, 1994: Métaxian et al. 1997; Rymer al., 1998; Maciejewski, 1998; Roche et al., 2001: Duffell et al., 2003 Williams-Jones et al., 2003), however, the exact depth, volume and shape of this reservoir are still unknown. At Masaya volcano, the continuous presence of fresh magma within a shallow magmatic reservoir is an extraordinarily persistent source of heat and gas (i.e., $\mathrm{H}_{2} \mathrm{O}$ $\mathrm{CO}_{2}, \mathrm{SO}_{2}$ ) (Duffell et al., 2003; Martin et al., 2010). In the vicinity of the magma reservoir, the heat will be mainly transferred to the country rock by conduction. While rocks are poor thermal conductors and cannot efficiently transfer heat throughout the entire edifice, volcanic gas and superheated aqueous fluids are excellent thermal conductors. which will both draw the heat from the magma and control heat distribution within the volcanic edifice. Consequently, sustained gas, superheated aqueous fluids and heat flux within the ground could generate and support hydrothenal fluid wirculation (Fizola et ald 2002; Chiodini et al., 2005; Bruno et al., 2007; Hase et al., 2010 an references therein). In the case of an open system such as at Masaya volcano, where the magma is directly in contact with the atmosphere. magmatic gases are easily evacuated through the open conduit and thus only a small percentage of the total gas flux may escape diffusely through the surrounding edifice. At Masaya, numerous studies have investigated the low temperature hydrothermal system of Comalito cone (Lewicki et al., 2003; Shaw et al., 2003; Pearson et al., 2008; Pearson, 2010), which has been described as a diffuse degassing structure (DDS) (Chiodini et al., 2005). However, at the calder scale only a few published studies have looked at the subsurface water flow or distribution of soil gas emissions (Crenshaw et a 982; St-Amand, 1999; MacNell et al., 2007).

Samalito cone are the only active degassing structures known in Masaya caldera, but the volino has of thy is to investigat the extent of the hydrothernal system throus is the caldera in order to better understand both groundwa ter flow and the shallow volcanic structures and their effect on the current and future volcanic activity. Five geophysical surveys were thus performed between February 2006 and March 2010 to lect $~ 81 \mathrm{~km}$ of self potential electrical profiles, $75 \mathrm{~km}$ of soil $\mathrm{CO}_{2}$ con $\sim 81$ trot (Fig. 3). Profiles of these measurements were then used to study the spatial and temporal variations of groundwater flow while multiscale wavelet tomography applied to the self-potential data enable characterization of water depths (Mauri et al., 2010, 2011).

2. Groundwater flow in active calderas layers, which may be connected through vertical water flow along faults and geological discontinuities (e.g., Zlotnicki et al., 1998; Finizola et al., 2002; Pribnow et al., 2003; Bruno et al., 2007). Very often within the hydrogeological structure, one or several hydrothermal systems may be present and supported by the volcanic heat/gas 2003). When not associated with active crater vents, these hydro(2003). Whe nost associated with active crater vents, hese hydrowhich systend permeality is higer due to fauts or fros) in (Chiodini a 2001 2005) The DDS can act as preferential che between the deep aquifer and the surface while in other parts of the volcanic edifice, the groundwater may consist solely of cold water flow. There are numerous examples of these hydrogeogical systems such as on Usu and Aso volcanoes (Japan), Long Valley calder the Hawaian Islands (USA) (Peterson, 1972; Sorey et al 1991: Hase et al. 2005: Hase et al. 2010). As calderas are usually coracterized by a topographic depression, it is common to find groundwate flow within the volcanic rocks as well as sizeable bodies of water on their surface (eg. Farrar et al., 2003; Pribnow et al. 2003: Join al., 2005; Pagli et al., 2006; Zlotnicki et al., 2009; Todesco et al., 2010) Hydrodynamic and chemical features of groundwater depend on the physical and chemical properties of the host rock (i.e., porosity, permeability, chemical composition, temperature, Seaber, 1988; AlAswad and Al-Bassam, 1997), however, without well information, it is often difficult to determine these properties. For this study, no well data are available, thus it is not possible to describe groundwate flow through its physical parameters (porosity, permeability). How ever, the groundwater flow direction can be characterized throug the self-potential elevation gradient (see Section 4.1) (Lénat, 2007). Therefore, as in other studies (e.g., Zlotnicki et al., 1998; Lénat, 2007; Finizola et al., 2009 and references therein) and independent of its chemical composition, groundwater flow will be separated into two groups based on the flow direction:

The first group, called gravitational flow (GF), includes any groundwater flow having its flow direction characterized mainly by a horizontal component. The second group, the uprising flow (UF) comprises any groundwater flow characterized by a major vertica component of the flow direction. When the fluid pressure becomes stronger than gravitational forces, groundwater rises along the structural limit (e.g., fault plane, rock discontinuities) having the highest hydraulic conductivity. The uprising flow is also called artesian flow when it reaches the surface (Banton and Bangoy, 1997) and is always the consequence of increased fluid pressure. This can be due to two processes. First, when the uprising flow originates from a confined or semi-confined aquifer, the fluid pressure builds up within the con1997) zone due to limited space (Banton and Bangoy, 1997; Drever 1997). Second, when the uprising flow originates from a geotherma and voir casing the fluid to ise toward the surface (Johnston et a V01, Zlo

in orde fro distinguish rising hydrothermal fluid (unconfined o to determine the three key characteristics that represent an uprising hydrothermal flow, notably flow direction, soil gas concentration and anomalos ground tementure (Finizola et al. 2002,2009 and references therein).

\section{Methods}

3.1. Self-potential

Self-potential (SP) is a passive electrical method which measures 

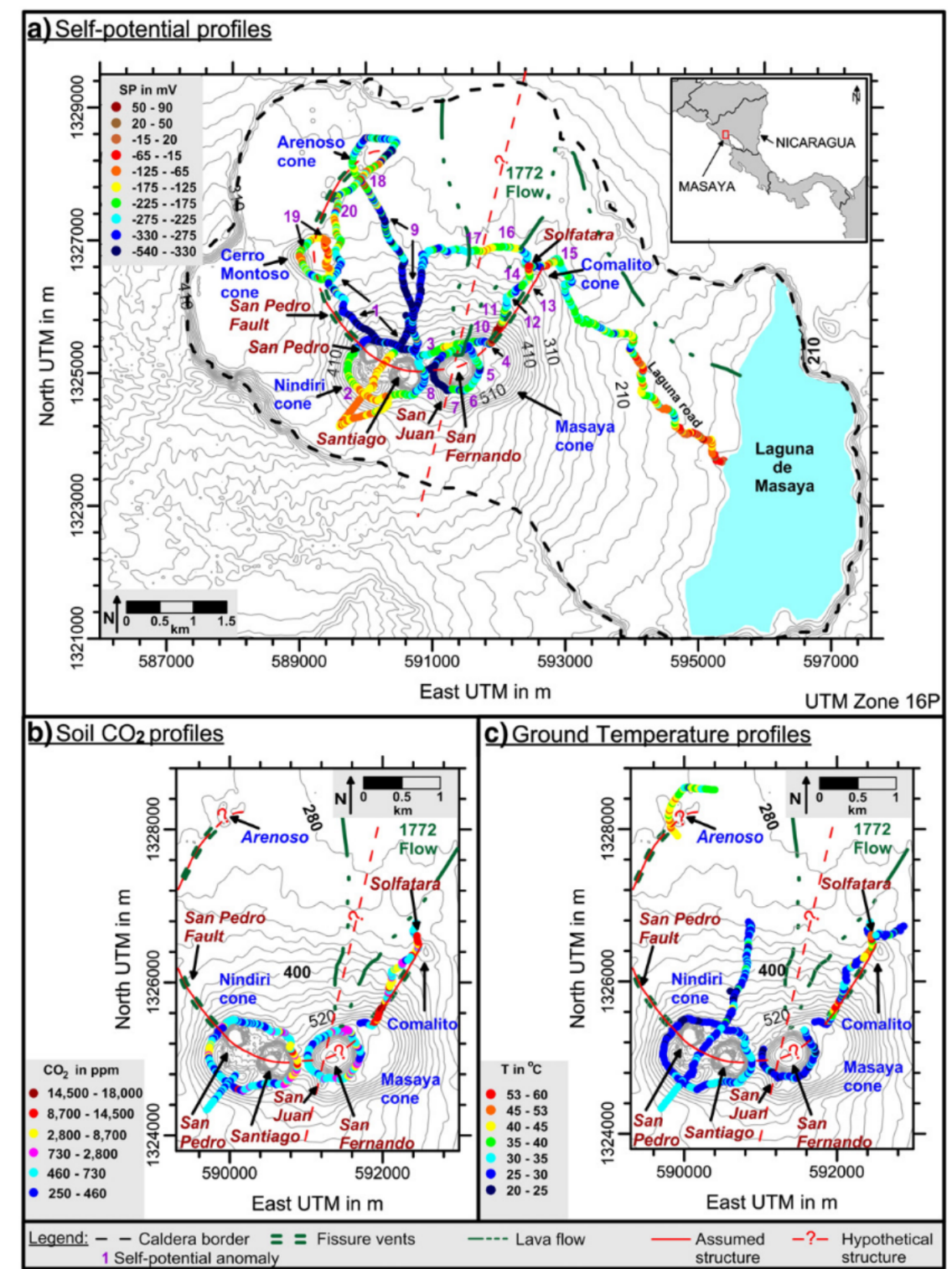

Fig. 3. Map of the profile measurements made between 2006 and 2010 in Masaya caldera, Nicaragua. a) Self-potential profiles overlain on the tectonic setting presented in Fig.

et al., 2002; Zlotnicki and Nishida, 2003; Lénat, 2007; Jouniaux et al., 2009 and references therein). A natural electrical current is generated by a number of different processes which include several physical and chemical phenomena. The most important sources of electrical generprocesses. al., 2008; Jouniaux et al., 2009). EK is affected by several key parameters including the chemicalcomposition of the water and the zeta potential, which is the electrical expression of the interaction between ions along the Helmholtz double layer (Hase et al. 2003: Aizawa et al., 2008). With an increase in flow pressure, the quantity of ions removed from the surface of minerals constituting the rock will in- 
mineral (Avena and DePauli, 1996; Guichet and Zuddas, 2003; Hase et al., 2003). Rapid fluid disruption (RFD) is an ephemeral phenomenon which characterizes water phase changes from liquid to vapor an will be expressed by an increase of the rising water flux (Johnston et al., 2001). The thermoelectric process occurs when heat flux (e.g. due to magnatic intron (Corwin and to a reck 1979). All of a therma gradient by conduction (Corwin and Hoover, 19f9). All of these proesses are always related in

Frocess and RFD, the ions are move via fluid flow (liquid or gas), while for the thermoelectric process, ther significant phenomen is the effect of heterog ine resistivity on the electrical potential (Salhac and Marquis, 2001 ; Saracco et a 2004). Previous studies (e. Minsley et al, 2007) have shown that resistivity contrasts, when not spatially associated with water flow (i.e. electrokinetic effect), may in some instances be of significant importance, In this study, however, and based on previous work, the main resistivity contrasts are considered to be as sociated with the pathway of the main ground water flow (MacNeil al., 2007; Mauri et al., 2010). A more detailed description of selfpotential electrical generation can be found in the literature (Ewing 1939; Poldini, 1939; Corwin and Hoover, 1979; Avena and DePauli, 1996; Johnston et al., 2001; Guichet and Zuddas, 2003; Hase et al. 2003; Zlotnicki and Nishida, 2003; Lénat, 2007; Aizawa et al., 2008; Finizola et al., 2009; Jouniaux et al., 2009).

On Masaya volcano, RFD is considered to be the main electrica source generation process in the hydrothermal environment, such as in the Comalito solfatara (Lewicki et al., 2003; Pearson et al. 2008). Otherwise, the electrokinetic process is the main source ectrical generation due to gravitational ground water flow (Lewicki et al., 2003). Thus, both the electrokinetic effect and RFD are considered as the source of electrical generation on Masaya volcano.

In this study, self-potential surveys were made using two copper electrodes, consisting of a copper rod in a saturated copper-sulphate solution, connected to a $350 \mathrm{~m}$ long insulated copper wire cable an a high impedance $(100 \mathrm{MOhm})$ multimeter. A sampling step of $20 \mathrm{~m}$ was used and the profiles were organized in interconnected loops to control the SP drift, which was never more than $40 \mathrm{mV}$. Electrode polarization was controlled at least twice a day and never exceeded more than $2 \mathrm{mV}$ and generally was close to $0 \mathrm{mV}$. A tota of $\sim 81 \mathrm{~km}$ of profiles were completed between 2006 and 2010 (Fig. 3a).

\subsection{Soil $\mathrm{CO}_{2}$ concentration}

The first magmatic gas to exsolve from the magma, $\mathrm{CO}_{2}$, rises prefrentially through magma and country rock along the main structur 2007). White $500 \mathrm{pm}$. $0>95 \%$ within the soil pore spaces (e. Williams-Jones et 2000: Federico et al 2010). However biogenic activity may also release $\mathrm{CO}_{2}$ through the root systems and generate up to a few $1000 \mathrm{ppm} \mathrm{CO}_{2}(\mathrm{e} \sigma$. Widén and Majdi, 2001). There are likely mutiple sources for the diffuse $\mathrm{CO}_{2}$ and accurate discrimination of the sources requires carbon isotope analyses (e.g. Chiodini et al. 2008) that were beyond the scope of this study. Therefore, for this study, $\mathrm{CO}_{2}$ ground concentrations between 400 and $1000 \mathrm{ppm}$ are only considered to be potentially of magmatic origin if the surrounding vegetation is null or sparse. Measurements of soil $\mathrm{CO}_{2}$ gas concentration were made by inserting a probe $60 \mathrm{~cm}$ into the ground and pumping measurements were made with a sampling step of $20 \mathrm{~m}$ in the same location as the self-potential measurements. In order to detect and control any drift of the device calibration, atmospheric $\mathrm{CO}_{2}$ concentration was measured at least each $100 \mathrm{~m}$, but generally every 20 $\mathrm{m}$. Soll $\mathrm{CO}_{2}$ concentration profles 1

3.3. Ground temperature

Hot/boiling gas and hydrothermal fluids lose their heat by conduction to the surrounding ground and by condensation of the gas. Over than $30 \mathrm{~cm}$ opth, is relay or less), the ground temperature at mo ture variation due to the poor thermal conduction of soil. Over longer time periods (weeks, months), atmospheric temperature variation can affect ground temperature to $1 \mathrm{~m}$ below the surface (Pearson al., 2008). On Masaya volcano, diurnal temperature variations a less than $5^{\circ} \mathrm{C}$ in amplitude, rain events can generate variations of $5{ }^{\circ} \mathrm{C}$ and volcanic events can cause a temperature variation up to $10^{\circ} \mathrm{C}$ over a short period of time (less than 1 day) (Pearson et al., 2008). When no magmatic heat source is present, the temperature of the ground is commonly below the atmospheric temperature $\left(>20^{\circ} \mathrm{C}\right)$. When the ground is heated by hot rising gas or hot/boiling hydrothermal fluids, the ground temperature can reach $75^{\circ} \mathrm{C}$ on Masaya volcano (Lewicki et al., 2003; Pearson et al., 2008; Pearson, 2010). On other volcanoes, ground temperature can reach more than $300{ }^{\circ} \mathrm{C}$ and is usually linked with $\mathrm{CO}_{2}$ gas anomalies and thus allows for detection of the main fracture pathways (e.g., Finizola et al., 2004; Chiodini et al., 2005; Bruno et al., 2007 and references there in).

Ground temperature measurements were made with a temperature probe (K-type chrome-aluminum probe) having an accuracy of $-0.2^{\circ} \mathrm{C}$. Measurements were carried out at a depth greater than $30 \mathrm{~cm}$ with a sampling step of $20 \mathrm{~m}$ in the same location as both the self-potential and $\mathrm{soil}_{2} \mathrm{CO}_{2}$ measurements. In order to avoid artifacts due to the influence of the atmosphere, atmospheric temperature was measured at least once every $100 \mathrm{~m}$ (Fig. 3c); as no volcanic events (e.g., vent explosion), nor rainfall occurred during the measurements, the diumal variation is considered to be less than $5{ }^{\circ} \mathrm{C}$. Thus any ground temperature anomaly higher than $10^{\circ} \mathrm{C}$ above atmospheric temperature can be considered to be due to hydrothermal activity only.

\section{Analysis}

4.1. SP/elevation gradient

The self-potential method generally allows for the differentiation of gravitational groundwater flow (GF) from uprising hydrotherma fluids (UF) by evaluation of the SP/elevation gradient (e.g., Finizol ways ways and SP anomalies. For greatest accuracy, the SP/elevation gradient must be calculated on an SP profile made along the main slope direction, which is assumed to match that of the water flow. When an SP profile crosses a slope perpendicular to the main slope, it is not always possible to accurately characterize the type of groundwater flow. In this case, if no other SP profiles or other data (e. $\mathrm{CO}_{2}$ concentration, ground temperare) are available, the $\mathrm{SP}$ anomaly is uncertain and may be attributed to gravitational groundwater flow until further information becomes available

In this study, a hydrothermal system is considered to be the source 
and ground temperature) are present, it can be interpreted with confidence that a hydrothermal system is present (Zlotnicki et a., 1958; fnizola et al., 2002, 2009). However, it is not always possible to acquire data from all three methods, thus when the such as sech as described in the litera

4.2. Multi-scale wavelet tomography

Multi-scale wavelet tomography (MWT) is a signal processing method based on continuous wavelet transform (CWT) (e.g., (c) When multi-scale plied to potential field data it allows for depth determination of the object penerating the measured potential field anomaly (Moreau et al., 1997, 1999; Fedi and Quarta, 1998; Sailhac et al. 2000: Gibert and Pessel, 2001: Sailhac and Marquis, 2001: Sarace et al 2004; Fedi et al., 2005; Cooper, 2006; Fedi, 2007; Saracco et al, 2007: Mauri et al 2010). MWT on self-potential data allows us to estimate the depth of the electrical source, which in the case of groundwater flow is the main flow pathway (Sailhac and Marquis, 2001: Saracco et al., 2004, Mauri et al., 2010). As shown by previous studies, the effect of a strongly heterogeneous resistivity medium (contrast of 3 orders of magnitude) on CWT depth accuracy can be efficiently mitigated by making multiple analyses (Mauri et al., 2010). Based on the Poisson kernel family, this study uses the following four real wavelets: second $(n=2)$ and third $(n=3)$ vertical derivative (V2 and $V$, respectively) and second and third horizontal derivative (in $1 \mathrm{D}, \alpha=-2$ and in $2 \mathrm{D}, \alpha=-3$ ) and monopole (in 1D, $\alpha=1$ a (in $1 \mathrm{D}, \alpha=-2$ and in $2 \mathrm{D}, \alpha-3$ ) and monopole (in $1 \mathrm{D}, \alpha=-1$ and in (S) 2001: Zlotnicki and Nishida, 2003: Saracco ( a. 2004: Lénat, 2007). In order to obtain reliable source depths, each 1D self-potentil profie was alo 500 diations on a ding analyzing wavelets. Only depths found with at least three of the four wavelet analyses are considered significant A more detailed description of MWT an be found in the works of Saracco et al. (2007) and Mauri et al. $(2010,2011)$ and references therein.

\section{Results and discussion}

In order to spatially represent, without interpolation errors, the self-potential, soil $\mathrm{CO}_{2}$ concentration and ground temperature data across the caldera, each data point was presented by a colored dot (Fig. 3); the color scales were chosen to best represent the structure shown in the profiles (Figs. 4 to 8 ). Water flow directions and type are based on the profile analyses summarized in Table 1.

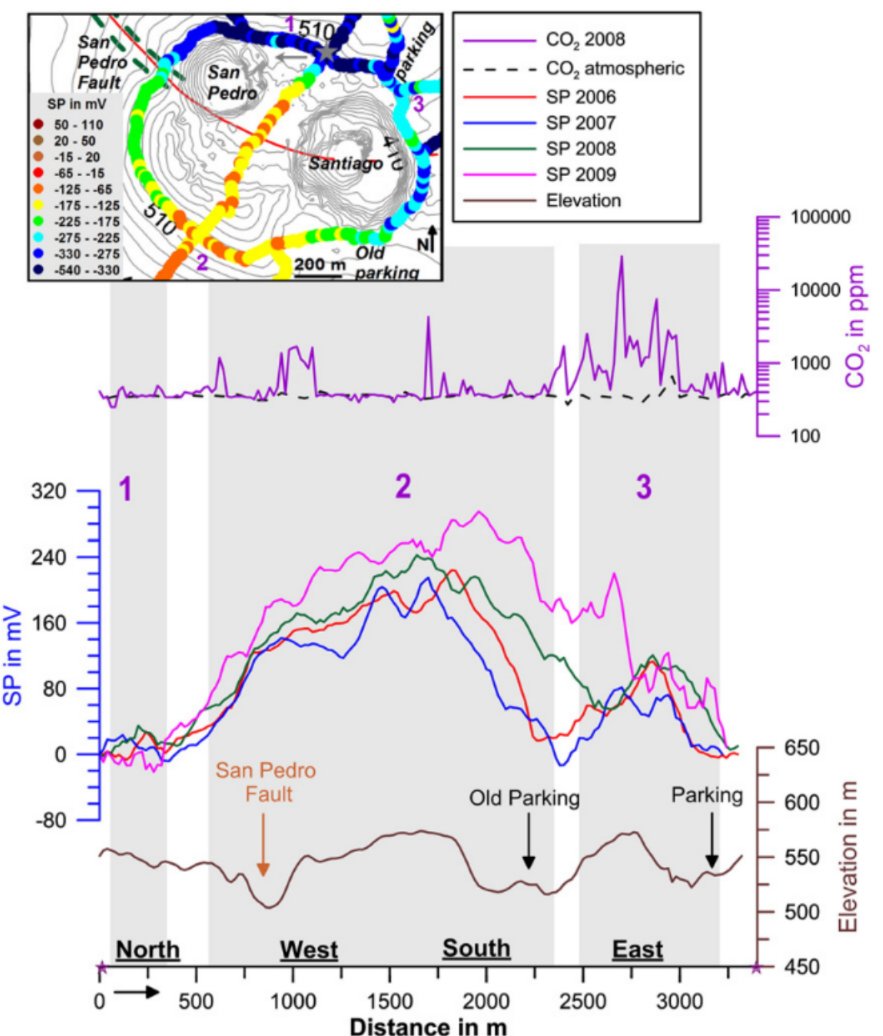




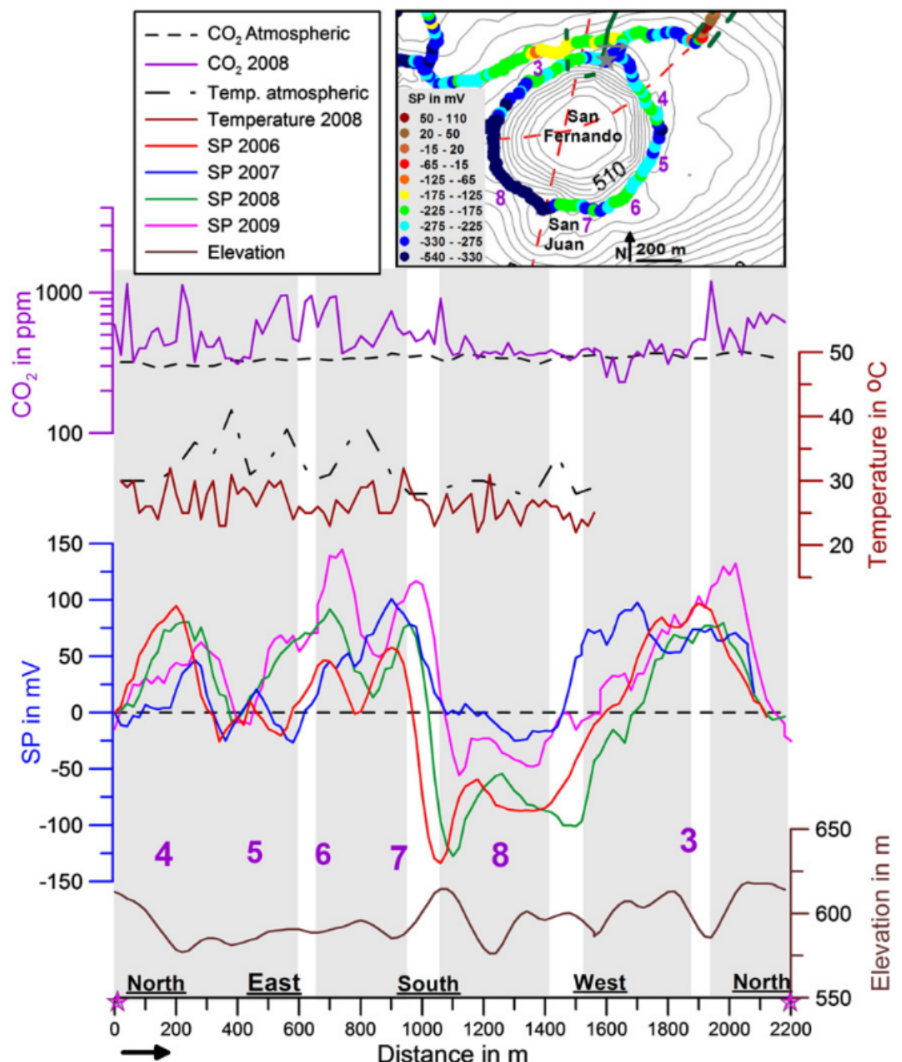

Fig. 5. Self-potential, $\mathrm{CO}_{2}$ soil concentration, ground temperature and topography of the survey profile around Masaya crater measured between 2006 and 2009 . All self-potential facilitate comparisen between different surveys. The purple numbers (and shaded areas) represent the anomalies reported in Table 1 . Sampling step is $20 \mathrm{~m}$. The star indicates the beginning and end of the profile. (For interpretation of the references to color in this figure legend, the reader is referred to the web version of this article.)

\subsection{Self-potential data}

In order to best organize the different electrical anomalies present on the different self-potential profiles, the self-potential/elevation chench (a) (5) lyses of each profie by $\mathrm{SP}$ elevation gadient wer made with ynsmo profies.

strong negative self-potential/elevation gradi(associated with strong negative SP values), several ectrical anomalies are interpreted as gravitational downwar in Fig 3 a by the blue colors (dark and light patte and represented itational flows are found on the south-east part of San Fernando crater on Masaya cone and throughout the caldera floor zone located within an area encircled by the main volcanic cones (Fig. 3a). This study finds no evidence for distinct individua gravitational flow systems, which is consistent with the MacNeil gravitational flows (Table 1, anomaly \#1, \#8, \#9, \#16) are considered to represent different areas of the same groundwate system.

On the eastern part of Masaya caldera, along the Laguna road from Comalito cone to Laguna de Masaya, several electrical anomlies are present (Fig 3a) however this self-potential profile is the only section that is not closed in a loop and thus cannot be corrected for SP drift. As such, these anomalies cannot be properly defined by the self-potentialelevation gradient. However, as they were fornd both in 2007 and 2008, these electrical anomas a likely not due to noise and could be actual anomalies showing local irregularities in the water table, subsurface resistivity or in hydrothermal circulation.

In the western part of Masaya caldera, as all SP profiles are in loop and thus properly corrected for any SP drift, it was possible to characterize fifteen electrical anomalies. These SP anomalies show both positive and negative SP/elevation gradients (Table 1, anomalies \# 2 to \#6, \#10 to \#15, \#17 to \#19), which indicate uprising water flow at depth. Furthermore, these anomalies are present on each of the cinder cones (Nindiri cone in Fig. 4, Masaya 


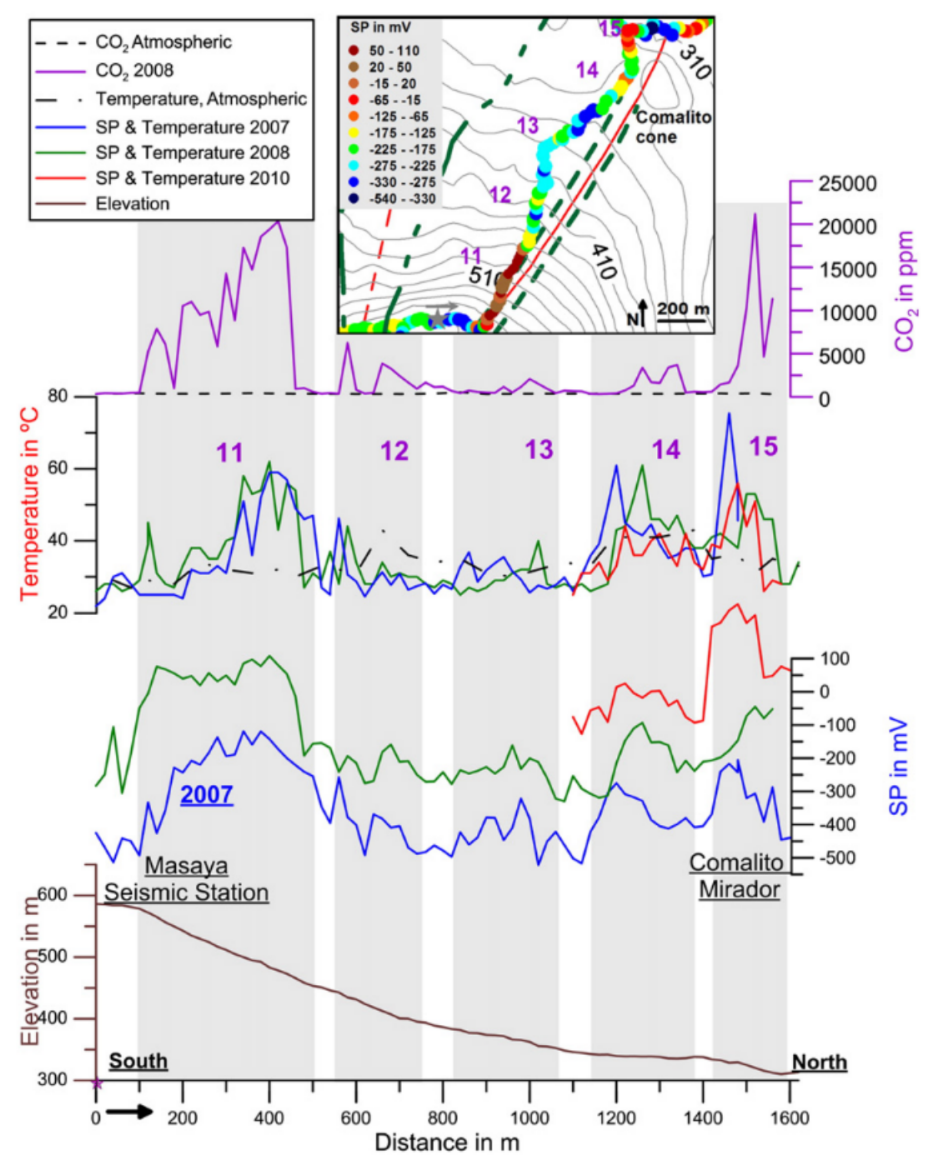

Fig. 6. Self-potential, $\mathrm{CO}_{2}$ concentration, temperature and topography of the survey profile across the north flank of Masaya cone to the solfatara of Comalito measured in 2007 and tributed to facilitate comparison of the different surveys. The purple numbers (and shaded areas) represent the anomalies reported in Table 1 . Sampling step is $20 \mathrm{~m}$. The star indicates the beginning and end of the profile. (For interpretation of the references to color in this figure legend, the reader is referred to the web version of this article.)

Fig. 7). Based on the self-potential mapping, the different uprising flows do not, at least on the surface, appear to be spatially consition (Table 1).

5.2. Ground temperature

Ground temperature anomalies have only been found in the Comalito solfatara (mean of $43^{\circ} \mathrm{C} \pm 8^{\circ} \mathrm{C}$ with a peak of $74{ }^{\circ} \mathrm{C}$ in 2007) and on the fissure vent cutting through the north slope of in these two (Fig. 6). From year to year, the ground temperatures anomalies correlate each time with self-potential anomalies and asymmetric self-potentialelevation gradients, which represent uprising fluids (Fig. 6. Table 1). These ground temperature anomalies also correlate with measured soil $\mathrm{CO}_{2}$ concentrations (Fig. 6 . Table 1). Our results support the previous observations for this area and show a similar extent to other studies (Lewicki et al., temperature variations are always correlated with measured atmospheric variations.

5.3. Soil gas concentrations

Previous isotopic studies of the $\mathrm{CO}_{2}$ gas measured on Comalito cone have shown that the $\mathrm{CO}_{2}$ was the result of a mixture of mantle and deep carbonate sources (Lewicki et al., 2003) and that passive $\mathrm{CO}_{2}$ degassing in the caldera was associated to diffuse degassing structures (DDS) (Chiodini et al., 2005). Other studies have shown anomalous soil $\mathrm{CO}_{2}$ concentrations on Arenoso cone and on the In the early 1980s, Masaya cone (St-Amand, 1999; Pearson, 2010). the presence of faults on the caldera floor (Fig. 1). which correspond to the Cofradrias fault as well as to a hypothetical buried circular tructure along the main volcanic features (e. Nindiri cone, Masaya cone, Comalito, Arenoso and the western fissure vents) (Crenshaw et (.. 1982). 


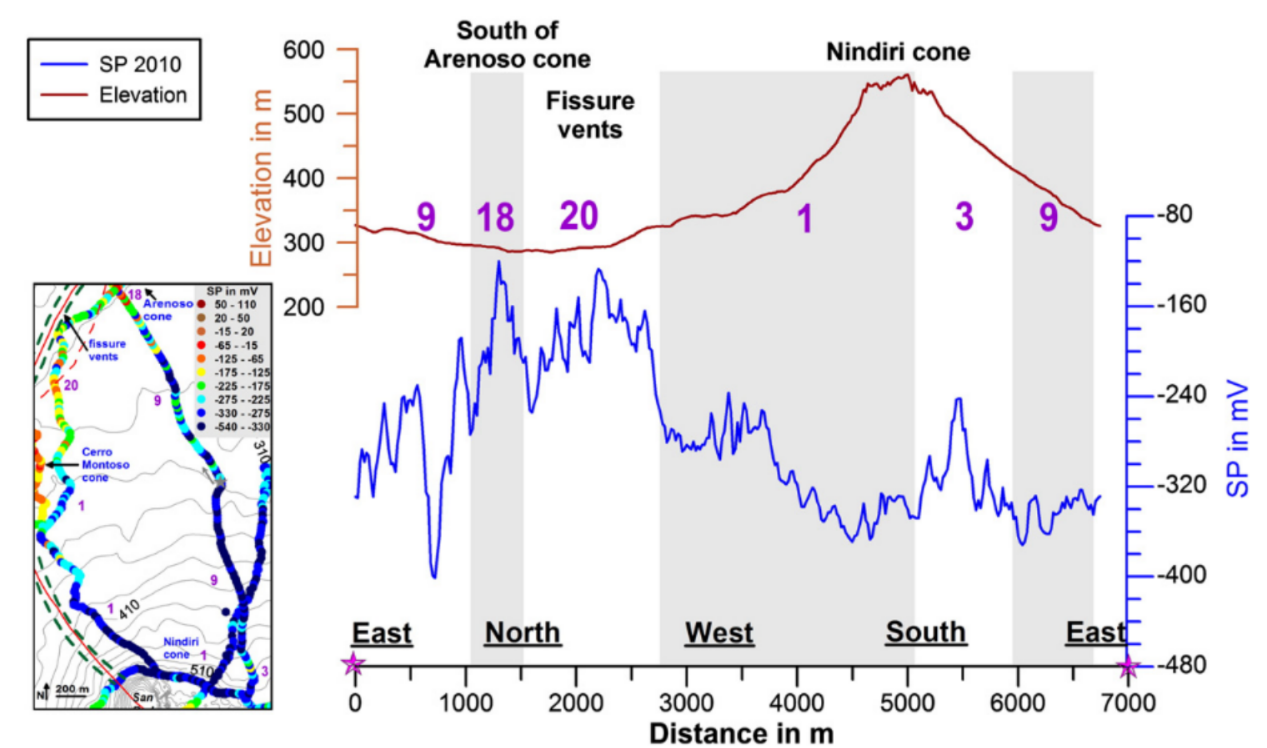

Fig. 7. Self-potential survey on the north part of Masaya caldera. All the self-potential profiles are referenced at the same base station to the Laguna de Masaya, which is assumed to

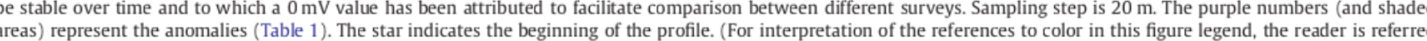
to the web version of this article.

only $7.5 \mathrm{~km}$ of profile, it is clear that the stronger degassing area found by this study is located in the fissure vent cutting through the north slope of Masaya. This large anomaly (400 $\mathrm{m}$ in length) has a mean concentration of $9,363 \mathrm{ppm}$ with a maximum of $\sim 20,000 \mathrm{ppm}$
and has good spatial co-variations with both ground temperature and self-potential anomalies (\#11, Fig. 6). Another area showing a diffuse $\mathrm{CO}_{2}$ and $\mathrm{SP}$ anomaly measured in this study (\#3, Fig. 5).

significant amounts of soil $\mathrm{CO}_{2}$ is the solfatara of Comalito (Table 1 , $\# 15$, Fig. 3), also detected in other studies (Lewicki et al., 2003; Chiodini et al., 2005; Pearson, 2010). As shown in the work of Crenshaw et al. (1982), a north-south fault cuts through San

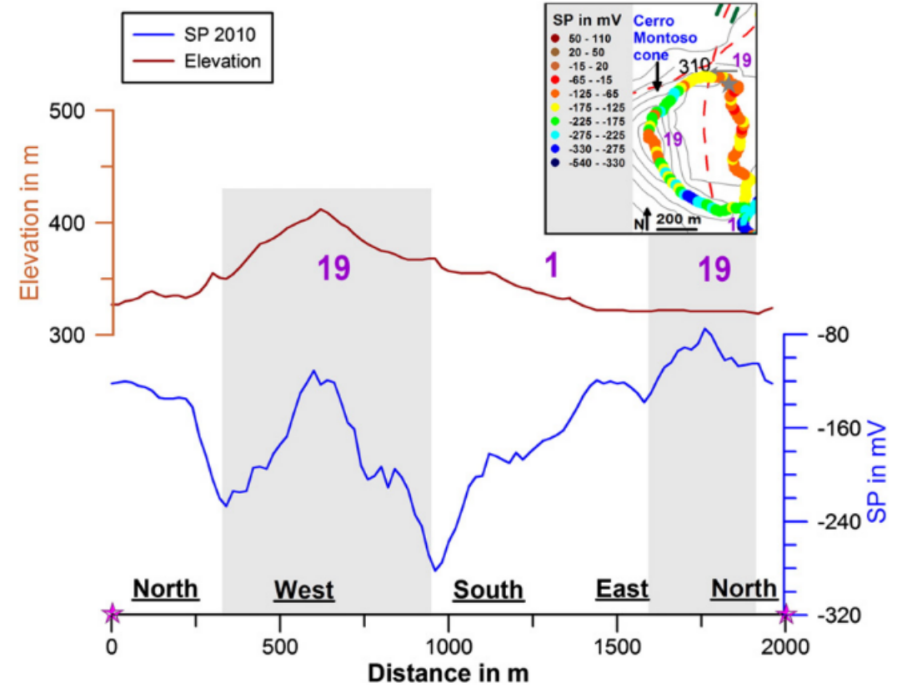


Table

Description of the different anomalies based on the self-potential amplitude, SP/elevation gradient, ground temper ature and soil gas measurements between 2008 and 2010 . North, South, because it shows no significant trend and could not be translated into an SP/elevation gamalies. Nart: no data exist for the associated SP anomaly. Und: SP vs. elevation data is undefined (1982): b from the work of Lewicki et al. (2003): ' from the work of St-Amand (1999): 'A from the work of Pearson (2010). Rank represents the certainty on the determination of the anomaly and is organized in

\begin{tabular}{|c|c|c|c|c|c|c|c|c|c|c|c|c|c|c|c|c|}
\hline \multirow[t]{2}{*}{$\begin{array}{l}\text { SP } \\
\text { anomaly }\end{array}$} & \multirow[t]{2}{*}{ Flow structure name } & \multirow[t]{2}{*}{$\begin{array}{l}\text { Profile length } \\
(\mathrm{m})\end{array}$} & \multirow[t]{2}{*}{$\begin{array}{l}\text { SP ampl. } \\
(\mathrm{mV})\end{array}$} & \multicolumn{5}{|c|}{$\begin{array}{l}\text { SP/elevation gradient } \\
\left(\mathrm{mV} \mathrm{m}^{-1}\right)\end{array}$} & \multicolumn{2}{|c|}{$\begin{array}{l}\text { Ground } \\
\text { temp. } \\
\text { (ec) }\end{array}$} & \multicolumn{2}{|c|}{$\begin{array}{l}\mathrm{CO}_{2} \text { soil } \\
\text { gas conc. } \\
\text { (ppm) }\end{array}$} & \multicolumn{3}{|c|}{$\begin{array}{l}\text { Previous soil } \\
\text { gas studies } \\
\text { (presence) }\end{array}$} & \multirow[t]{2}{*}{ Rank } \\
\hline & & & & $\mathrm{N}$ & $\mathrm{s}$ & E & $\mathrm{w}$ & c & Mean & $\sigma$ & Mean & $\sigma$ & $\mathrm{Rn}$ & $\mathrm{Hg}$ & $\mathrm{CO}_{2}$ & \\
\hline 1 & GF & 1000 & 200 & -0.3 & Nan & -1.6 & -0.7 & Nan & 26 & 2 & 368 & 54 & No & No & Nan & A \\
\hline 2 & Nindiri HS & 1500 & 200 & & & & & & 28 & 2 & & 509 & Yes $^{2}$ & Yes $^{\mathrm{a}}$ & & ${ }_{1}$ \\
\hline 3 & Masaya-Nindiri Junction HS & 500 & 150 & -4.3 & -1.3 & +4.5 & -0.5 & Nan & 30 & 2 & 1934 & 4318 & Nan & Nan & Nan & A \\
\hline 4 & NE Masaya HS & 300 & 100 & -2.3 & $\mathrm{Nan}$ & +11.4 & Nan & Nan & 27 & 3 & 549 & 260 & Yes $^{2}$ & Yes $^{a}$ & Nan & A \\
\hline 5,6 & SE Masaya HS & 500 & 100 & Nan & -7.3 & +6 & Nan & Nan & 27 & 2 & 584 & 233 & Nan & Nan & Nan & A \\
\hline 7 & San Juan HS & 260 & 180 & Nan & Nan & +1.4 & -9.9 & Nan & 28 & 3 & 32 & 115 & Nan & Nan & Nan & A \\
\hline 8 & GF & 300 & 80 & Nan & -1.5 & Nan & -1.9 & Nan & 26 & 2 & $27>>2$ & 131 & Nan & Nan & Nan & A \\
\hline & GF & 1500 & 150 & -3 & -1 & -12.6 & -58.8 & Nan & 29 & 3 & Nan & Nan & Nan & Nan & Nan & B \\
\hline 10,11 & Masaya N. slope HS & 600 & 300 & +11.5 & -9.3 & Nan & Nan & -0.4 & 41 & 11 & 9363 & 6601 & Nan & $\mathrm{Nan}$ & Yes $^{c}$ & A \\
\hline 12 & Masaya N. slope HS & 200 & 150 & +2.2 & +4.9 & Nan & Nan & Nan & 32 & & 2233 & 1952 & Nan & Nan & Yes $^{\mathrm{d}}$ & A \\
\hline 13 & Comalito HS & 150 & 100 & +4.9 & -2.7 & Nan & Nan & Nan & 29 & 4 & 001 & 458 & Yes $^{2}$ & Yes $^{\mathrm{a}}$ & Yes $^{\mathrm{b}, \mathrm{c}, \mathrm{d}}$ & A \\
\hline 14,15 & Comalito HS & 200 & 200 & -7.2 & -56.9 & +38 & +20.7 & -10.5 & 43 & 8 & 4202 & 5354 & Yes $^{a}$ & Yes $^{\mathrm{a}}$ & Yes $^{\mathrm{h}, \mathrm{cl}}$ & A \\
\hline 16 & GF & 300 & 120 & Nan & Nan & -17.3 & -46.7 & Nan & Nan & Nan & Nan & Nan & № & No & Nan & D \\
\hline 17 & 1772 lava flow HS & 650 & 100 & +20 & -4.6 & Nan & Nan & Nan & Nan & Nan & Nan & Nan & No & No & Nan & D \\
\hline 18 & Arenoso HS & 500 & 100 & +3.5 & +20.3 & Und & Nan & Nan & 40 & 5 & Nan & Nan & $\mathrm{Yes}^{\mathrm{a}}$ & Yes $^{a^{2}}$ & $\mathrm{Yes}^{\mathrm{c}}$ & B \\
\hline 19 & $\begin{array}{l}\text { Cerro Montoso HS } \\
\text { Yent fissur HS }\end{array}$ & 700 & 300 & $\begin{array}{l}\text { Und } \\
\text { G5 }\end{array}$ & $\begin{array}{l}+2.6 \\
-0.69\end{array}$ & Nan & +2.2 & Nan & Nan & Nan & Nan & Nan & $\begin{array}{l}\text { Nan } \\
\text { Yea }\end{array}$ & $\begin{array}{l}\text { Nan } \\
\text { Yape }\end{array}$ & Nan & D \\
\hline 20 & Vent fissure HS & 1300 & 160 & 6.54 & -0.69 & Nan & Nan & Nan & Nan & Nan & Nan & Nan & $\mathrm{Yes}^{\mathrm{a}}$ & Yes $^{a}$ & & \\
\hline
\end{tabular}

5.4. Groundwater depth

Multi-scale wavelet tomography of the 5 years of SP profiles resulted in more than 500 depth values that represent the depths of the main electrical generation sources, interpreted as main groundwater pathways. The MWT analyses have been done on smoothed profiles ( 5 point moving average) to remove high frequency noise. To avoid artifact depths, only estimated depths found with at least 3 of the 4 analyzing wavelets are considered significant (Appendix 1). By comparing the horizontal position of each anomaly associated to each depth, it was possible to characterize 31 time-series data sets, which represent 99 individual depths well localized in space (GP depth) and time (from 2006 to 2010) (Table 2, Appendix 1).

While the spatial distribution of the water depths are limited to the self-potential coverage of the caldera, the estimated water depths relative to the topographic surface are quite constant across the caldera following the topographic variation (Table 2). $47 \%$ of the water depths are between 50 and $100 \mathrm{~m}$ below the topographic surface and $83 \%$ of the depths are less than $150 \mathrm{~m}$ below the topographic surace. A similar distribution is found if the depths are discriminated between uprising water and gravitational water flow (Table 2). In addition, each depth value has an error bar (one standard deviation, $o z$ ) which represents the scattering of all the raw estimated depths associated to this value, $O z$ is less than $50 \mathrm{~m}$ for $79 \%$ of the estimated depths and the mean of the error for the 99 estimated depths is $36 \mathrm{~m}$ (min. value of $11 \mathrm{~m}$ and max. of $68 \mathrm{~m}$, Table 3). Similar values were

Scattering of the depth values $(\mathrm{Gz})$ and significance of water depth interpretation. The scattering of the individual data can be found in Appendix ?

All system Gravitational Uprising flow flow

$\begin{array}{lllllll}\text { Total } & 99 & 100 & 33 & 100 & 66 & 100 \\ \text { Shallower than } 50 \mathrm{~m} & 13 & 13 & 7 & 21 & 6 & 9\end{array}$

Shallower than $50 \mathrm{~m}$ found on a north-south profile across Nindiri (Mauri et al., 2010) and have been included in this study (diamonds and squares on Fig. 9b,d). Further north, within both Cerro Montoso and Arenoso cones, the water depth is between 50 to $120 \mathrm{~m}$ below the surface Table 1, Appendix 1). Even within the fissure on the north slope of Msac and on the Comalito solfatara, where the uprising flows are associated with the strongest hydrothermal activity, the water 列 way from the volcanic structures on the caldera floor, where the water flow is associated with gravitational flow, the water depths (he surface The MWT on self-potential data can only detect the shallowest water structure, any other structure below it will have its electrical signal overprinted by the shallowest one and as such, the deeper structures cannot be characterized. A model by MacNeil et al. (2007) proposed a gromiwater structure consisting of a series of overlying groundwater flow; the deeper layer is strongly affected by water vapoization mear the active vert of Santiago crater while the shallowest groundwater layer the cones towards the Laguna de Masaya. The water depth calculation

Number of depths for both aquifer and hydrothermal systems based on the results of Appendix 1 . Statistics of the estimated depths are from the multi-scale wavelet tomog-

\begin{tabular}{|c|c|c|c|c|c|c|}
\hline Scattering of $t$ & ertical & th values & in $n$ & ween 2006 & | 201 & \\
\hline $\mathrm{s}$ & 11 & $o z \max$ & 68 & $\mathrm{oz}$ mean & 36 & \\
\hline Range of & All de & & Upris & flow & & ional \\
\hline oz & Nbr & $\%$ & Nbr & $\%$ & $\mathrm{Nbr}$ & $\%$ \\
\hline sz & 99 & 100 & 66 & 100 & 33 & 100 \\
\hline less than & 0 & 0 & 0 & 0 & 0 & 0 \\
\hline$\sigma z<20$ & 14 & 14 & 8 & 12 & 6 & 18 \\
\hline$\sigma z<30$ & 36 & 36 & 21 & 32 & 15 & 45 \\
\hline
\end{tabular}




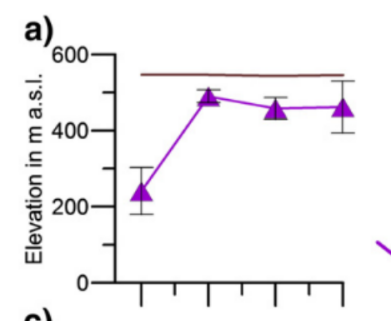

b)

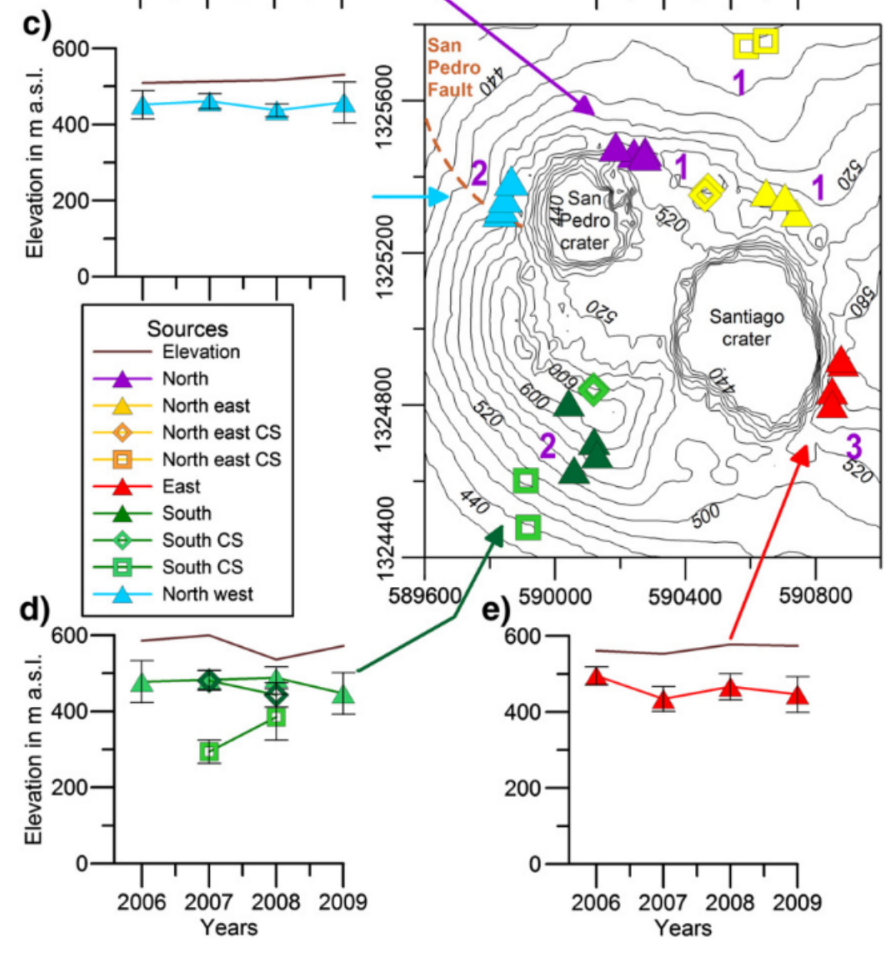
Fig. 9. Water depths between 2006 and 2009 on Nindiri cone. Horizontal GPS coordinates and depths of the water are obtained by multi-scale wavelet tomography applied on the
self-potential survey loop. Triangles represent depths calculated from the MWT analysis of the Nindiri survey loop (Fig. 5). Squares and diamonds are calculated depths from the MWT analysis of a Nindiri cross-section SP profile (from Mauri et all, 2010). All depths are presented in Appendix 1. (For interpretation of the references to color in this figure legend, the red

by MWT on SP data clearly shows the shallow water layer, although the depth is $\sim 100 \mathrm{~m}$ shallower than previously modeled by MacNeil et al. (2007).

This discrepancy in depth is likely due to differences in the sensitivity of each method. While the TEM method will characterize the large resistivity contrast associated to transition between the more conductive saturated zone and the less conductive unsaturated zone, the MWT method characterizes the main groundwater flow responsible for electrical generation. On one hand, TEM may not be sufficiently sensitive to detect a thin saturated zone in a complex heterogeneous volcapotential recerds shallowest saturated zone, allowing MWT on SP data to detect it independent of the thickness of the saturated zone. It is also possible that the presence of a high resistivity contrast (not associated to an aquifer)

Lacking any direct well data, it is difficult to determine which model est represents the true water depth.

Another possibility regarding the relatively shallow estimated depths is that there is locally significant water flowing within the unsaturated zone. However, such water circulation in the unsaturated zone is unlikely because field measurements were made during the dry season. Regarding the depth of the uprising flow associated to DDS, due to their limited surface extent, it is possible that they were not detected by the transient electromagnetic method (TEM) (Pearson, 2010) of the Comalito and North Masaya fissure support the idea of a water table at $250 \mathrm{~m}$ below the surface from which a localized escape path along fault allows the hot fluids to rise to the topographic surface. From a self-potential generation perspective, the hot uprising fluids, which generate a RFD electrical anomaly, would 


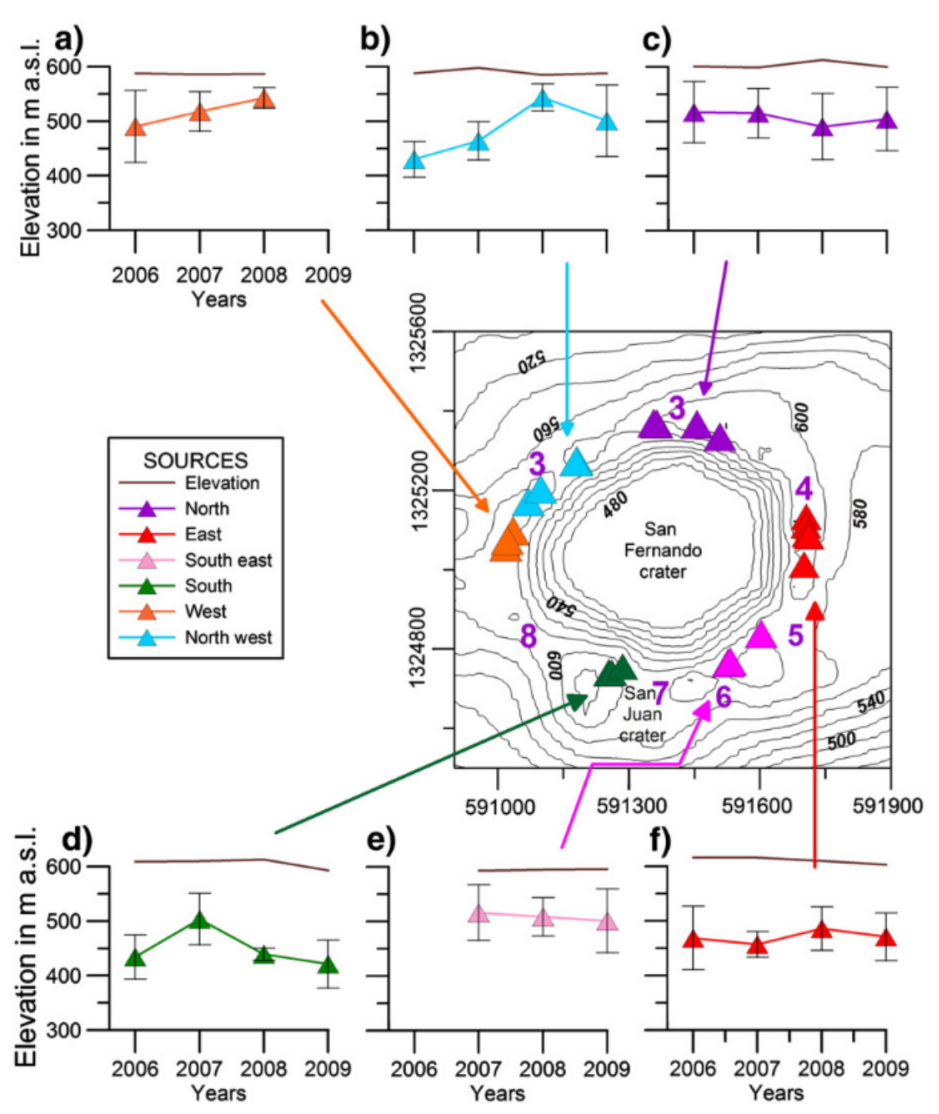

Fig. 10. Water depths between 2006 and 2009 around Masaya crater. Horizontal GPS coordinates and depths of the water are obtained by multi-scale wavelet tomography applied to the self-potential survey loop. Triangles represent depths calculated from the MWT of the Masaya SP survey loop (Fig. 5). All depths are presented in Appendix 1. (For interpre-

Over the period from 2006 to 2010, there was no significant change in the persistent volcanic activity of Masaya volcano (Martin et al., 2010). Over the same period of time, this study has shown water flow did Masaya and Nindiri cones, the depth of the ground(oz) (Figs 9,10$)$. In addition, similar depth stability is found in (oz) (Rigs. quently, while the unctanty on the depth value (uz) makes it diffcult to ware cherize any significant depth variation over time, the relative depth stability of groundwater flow may be due to the persistence of Masaya volcanic activity.

5.5. Diffuse degassing structures

As previously reported (e.g., McBirney, 1956; Crenshaw et al., 1982: Williams. 1983b) a number of structures related to previous collapse events and faults crosscut the caldera (solid lines and dashed red lines on Fig 13a). Fault displacements, if any, have been covered by recent lava flows making it impossible to characterize them over time and the only expression left of the inner structural limits are cinder cones and fissure vents (Fig. 13a). ground temperature. The self-potential results presented here and in previous studies (Lewicki et al., 2003; Pearson, 2010) show that the Comalito DDS is also characterized by uprising groundwater low (Table 1, anomalies $\# 13,14,15)$. On active volcanoes, uprising groundwater flow is typically associated with uprising hydrothermal the case of Masaya volcano, we may thus extend the defintion of DDS to be any area where both passive degassing ald uprising DDS to be any a a whe bous ure anomalies. On each of the five cinder cones within the caldera, uprising flows have been detected from SP-elevation gradients and each is associated with soil gas anomalies (Table 1 anomalies $\# 2$ to each is associated with soll gas ansing (Table 1, anomalies \#2 to cones and the north Masay fissure vent are also diffuse degassing structures. While no soil $\mathrm{CO}_{2}$ concentration or ground temperature data are available for Cerro Montoso cone, uprising flow was detected by the positive SP-elevation gradient (Table 1,\#19) suggesting that Cerro Montoso cone is also a diffuse degassing structure.

Although the fissure vent between Arenoso and Cerro Montoso cone is only partially covered by the SP survey, it appears to be associated with a positive SP anomaly (Table 1. Fig. 7, \#20) as well as with 


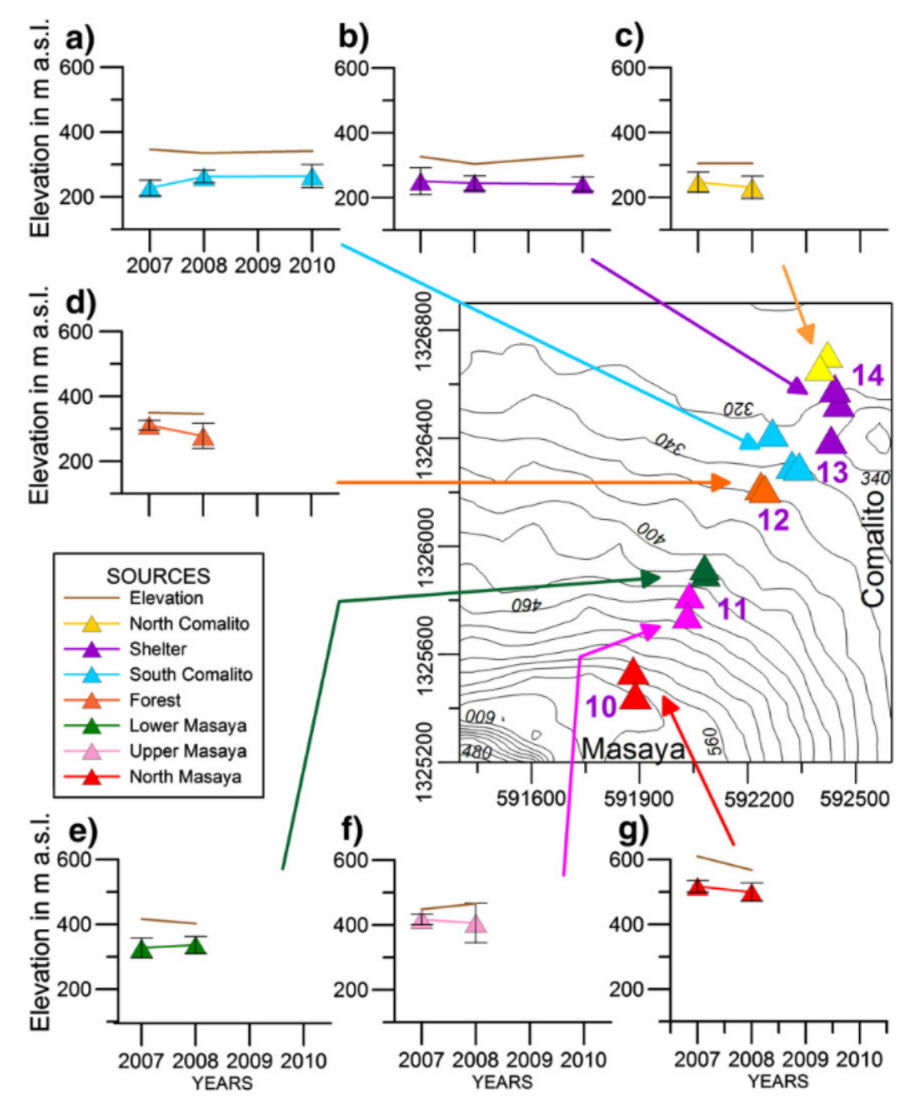

Fig. 11. Water depths between 2007 and 2010 across the north flank of Masaya cone until the solfatara of Comalito cone. Horizontal GPS coordinates and depths of the water are
obtained by multi-scale wavelet tomography applied on the self-potential survey loop. Triangles represent depths calculated from the MWT of the Comalito profile (Fig. 6). All depths are presented in Appendix 1. (For interpretation of the references to color in this figure legend, the reader is referred to the web version of this article.)

amplitude, low diffuse $\mathrm{CO}_{2}$ concentration and radon and mercury gas anomalies (Fig. 4; Crenshaw et al. (1982)). These two fissure vents should therefore also be considered as diffuse degassing structures. At the caldra scale,

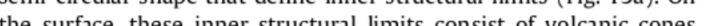
and fissure vents, while at depth, they likely consist of dyres and faults cutting through the calde flor, which at as preferentia pets calting the Importantly, this evidence for widespread hydrothermal activity rises significant questions regarding quantification of the thermat budget of the caldera complex and highlights the need for a more exensive caldera-wide degassing study (egr Chiodini et al. 2001).

\subsection{Hydrogeological systems}

With an understanding of the active caldera structures and groundwater depths, it then becomes possible to develop a groundwater flow model for Masaya (Fig 13b, c). Near the active vent of Santiago crater, groundwater is likely vaporized at depth leading to depletion of the deep water reservoir detected by MacNeil et al. quantity of precipitation will infiltrate the caldera floor to recharge the shallowest aquifer and possibly the deep aquifer. Away from the caldera rim and associated with the diffuse degassing structures, the inner structural limits likely consist of intruded dykes and faults cutting throught the caldera floor, these are expressed on the surface by potentias coil as potential, soll gas concentrest these in structur limits, which allow fluids to deepest aquer to the shallowest aquifer. The presence of hot rising fluids (gas, water) indicates that these inner structural limits are moving heat and gas from depth (red stars on Fir. 13b. c). the source of which is likely the shallow magmatic system, but which cannot be characterized from our results. These hydrothermal fluids will rise due to increased fluid pressure through the more fractured part of due to increased

In contrast, the shallow gravitational water flow generally mimics ward, until Laguna de Masaya. The top of the shallowest groundwater layer, based on the MWT analyses, is generally at less than $150 \mathrm{~m}$ below the topographic surface. In terms of elevation, the hydrothermal 

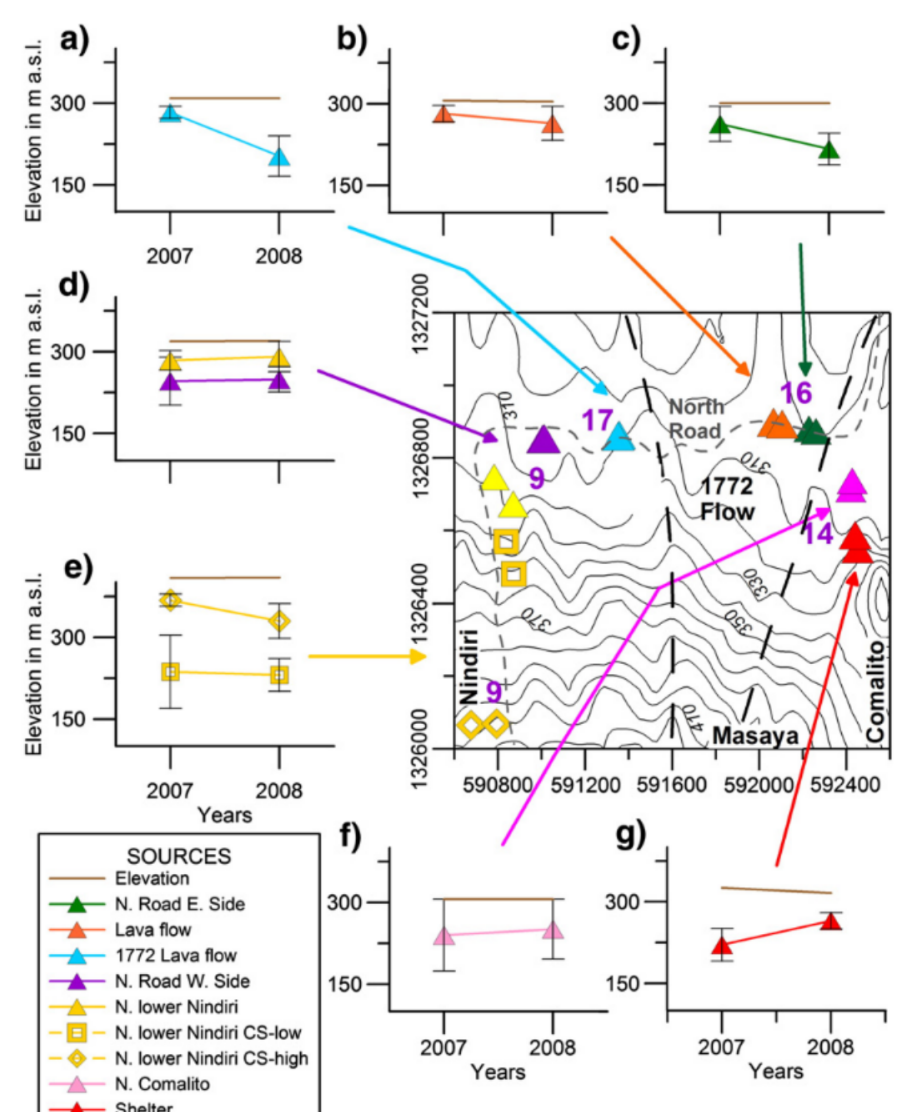

Fig. 12. Water depths between 2007 and 2008 along North road. Horizontal GPS coordinates and depths of the water are obtained by multi-scale wavelet tomography applied on of the Nindiri cross-section SP profile (Mauri et al, 2010). All depths are presented in Appendix 1. (For interpretation of the references to color in this figure legend, the reader is referred to the web version of this article.)

the lake whose surface represents the level of the deep aquifer (Fig. 13b, c) (MacNeil et al., 2007). However, our updated model highlights the significant role of the inner structural limits, which act as barrien in (hong (ing matic reservoir at depth Such sub-vertical to verticaldense in will act as hydratic baries foring he flownothwath This is corly the case on the noth side of the summitcoses. where the shallowa fer mimics the topographic decrease toward the northern caldera rim; er the north caldera rim, the flow diection hert arns east the lake.

\section{Conclusion}

This study presents an updated groundwater flow model that incorporates and highlights the existence of active volcanic structures cutting across the caldera floor. Multi-scale wavelet tomogshow that the shallowest phy, usually less than $150 \mathrm{~m}$ below the surface. Furthermore, uprising fluids are present within three volcanic fissures across the caldera; self-potential, and themperate drothermal in origin.

Fig. 13. Groundwater flow model for Masaya volcano. a) Spatial localization of uprising fluids associated to hydrothermal activity (green diamonds) and gravitational water flow (blue squares) within Masaya caldera for which depths have been determined (see Appendix 1 and text for description). The names of volcanic cones are in blue. The crater names 1982: Harris, 2009). The red dashed lines are the hypothetical structures (faults, fissures) (Crenshaw et all, 1982). The black dashed line is the inferred limit of the caldera. Deppth values can be found in Appendix 1. See text for description. b) Cross-section along profile A-D-B representing the water flow direction across the caldera. c) Cross-section along profile C-D-B representing the water flow direction through the active Santiago crater and across the caldera. The dashed red lines represent underground structures where the 

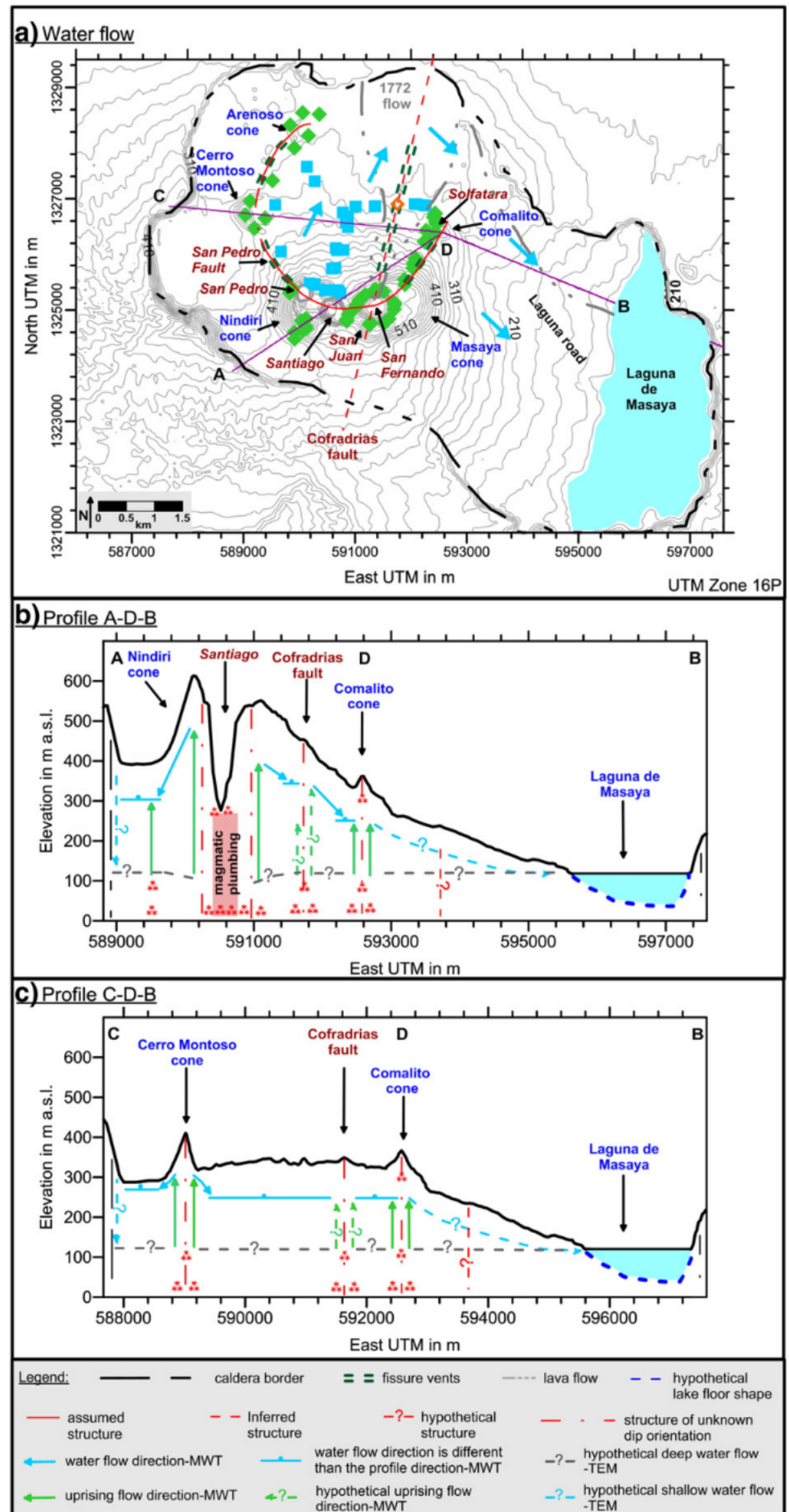
The presence of faults, fissures and dikes have two different effects on the hydrogeological system of Masaya volcano. The inner semicircular structure will channel the uprising hydrothermal fluid, while also acting as a barrier to lateral gravitational water flow. Furthermore, the uprising water and hot nagnatic gas escaping along tive pathways to both hydothermal systems and the shallow magthe path hrough the caldera and as such, the heat butget for the centrat part of Masala must be sigificuty lage han previouly thought Diffuse degassing structures are clearly not limited to the Comalito Difuse degassing structures are clearly not limited to the Comalito icant cante ain the mort rising along the DDS. For example, the injection of new magn depth would likely increase both gas and heat flux in the DDS fluids leading to stronger SP anomalies on the surface. Such changes in SP have been detected on other volcanoes preceding eruptions ( $\mathrm{eg}$ Finizola et al., 2009) and depth changes in the rising fluids can be detected by MWT on SP data (e $g$ Saracco et al. 2004). While Masaya volcano was in a steady state from 2006 to 2010 with no significant change in fluid depth detected, multi-scale wavelet tomography of self-potential surveys has proved to be an effective method for delineating active subsurface structures and monitoring fluctuations in hydrothermal systems that may precede changes in volcanic activity. Supplementary materials related to this article can be found online at doi:10.1016/.jvolgeores.2012.02.003.

\section{Acknowledgments}

This research was supported by an NSERC Discovery grant to G. Williams-Jones. The authors thank one anonymous reviewer, J-F. Lénat, O. Merle, G. Bertrand for their constructive comments. Many thanks to the Dirección General de Geofisica of INETER and the Parque Nacional Volcán Masaya for their continued support in Nicaragua. This study would not have been possible without the help of a large number of volunteer student field assistants.

\section{References}

Acocella, V., 2007. Understanding caldera structure and development: an overview of analogue mod 10.1016 awa, K., Uyeshima, M., Nogami, K., 2008. Zeta potent on 11 island arc-type volcanoes in Japan: implication for the generation of local
self-potential anomalies. Journal of Geophysical Research 113, B02201.

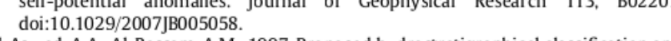
A-Aswad, A.A., Al-Bassam, A.M., 1997. Proposed hydrostratigraphical classification and nomenclature application to the Palaeozoic in Saudi Arabia. Journal
Earth Sciences 24 (4), 497-510. doi: 10.1016/50899-5362(97)00077-8. Avena, M.J., DePauli, C.P., 1996. Modeling the interfacial properties of an amorphous
aluminosilicate dispersed in aqueous NaCl solutions. Colloids and Surfaces A

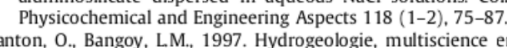

Banton, O., Bangoy, LM., 1997. Hycrogeologie, multiscience ennvironnmentale des
eaux soutercaines (Hydrologeology, enviren, Presses de l'Universite du Quebec/AUPELF, Sainte-Foy, Quebec. 460 pp. Bruno, P.P.G., Ricciardi, G.P., Petrillo, Z., Di Fiore, V.. Troiano, A., Chiodini, G... 2007. GeoSolfatara Volcano, Campi flegrei, Italy: response to caldera unrest. Journal of Geophysical Research 112, B6201. doi: 10.1029/2006/B004383.

Chiodini, G., Frondini, F., Cardellini, C., Granieri, D., Marini, L., Ventura, G., 2001. $\mathrm{CO} 2$ degassing and energy release at Solfatara Volcano,
Geophysical Research 106 (B8), 16,21 1 - 16,221 . Chiodini, G., Granieri, D., Avino, R., Caliro, S., Costa, A., Werner, C., 2005. Carbon dioxide diffuse degassing and estimation of heat release from volc anic and hydrothermal Chiodini, G., Caliro, S., Cardellini, C.. Avino, R., Granieri, D., Schmidt, A., 2008. Carbon

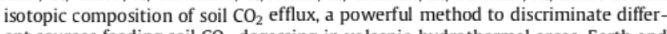
ent sources feeding soil $\mathrm{CO}_{2}$ degassing in volcanic-hydrothermal areas. Earth $\mathrm{za}$ Connor, C.B., Williams, S.N., 1990. Interpretation of gravity anomalies, Masaya caldera
Corwin. R.F. Hoover, D.B., 1979. Self-potential method in geothermal exploration. Geephysics 44 (2), 226-245.

政, cetection at an active volcano in Nicaragua. Nature 300, 345-346.

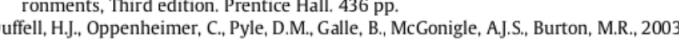
Nanges in gas composition prior to a minor explosive eruption at Masaya volcano, doi: 10.1016/S0377-0273(03)00156-2.

Ewing, S., 1939. The copper-copper sulfate half-cell for measuring potentials in earth. American Gas Association, Proceedings 21, 624-634.

Howle, J.F., Jacobson, R., 2003. Inferdera, from recent flow testing and geochemical sampling. Journal of Volcanology and Geothermal Research 127, 305-328.

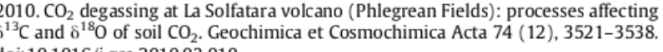
doi: 10.1016j.gca.2010.03.010.

Fedi, M., 2007. DEXP: a fast method to determine the depth and the structural index of
potential fields sources. Geophysics $72,11-111$. Fedi, M., Quarta, T., 1998. Wavelet analysis for the regional-residual and local separaFedi, M. Paoletti, V. Rapolla, A. 2005. The role of multilievel data in potential field interpretation. Computers \& Geosciences 31 (6), 681-688.

(A), A, Sortino, F., Lenat, J.F., Valenza, M. 2002. Fluid circulation at Strombolivolcano (Aeolian Islands, Italy) from self-potential and $\mathrm{CO}_{2}$ surveys. Journal of Volcanology
and Geothermal Research $116(1-2), 1-18$.

nd structural discontinuities inside Misti volcano (Peru) inferred from self-potential Finizola A Aubert, M. Revil A, Schütze C. Sortino, F. 2009 . Im history in the summit area of Stromboli during the 2002-2003 eruptive crisis inferred from temperature, soil $\mathrm{CO}_{2}$, self-potential, and electrical resistivity tomogra-
phy, Journal of Volcanology and Geothermal Research 183, 213-227. doi: 10.1016/
j.jvolgeores.2009.04.002.

Gibert, D., Pessel, M., 2001. Identification ous wavelet transform: application to self-potential profiles. Geophysical Research
Letters 28 (2) Grossmann, A. Morlet, J., 1984. Decomposition of Hardy functions into square integrable
wavelets of constant shape. SIAM Journal on Mathematical Analysis $15(4), 723-736$. effect of secondary minerals on electrokinetic phenomena doi: $10.1029 / 2003$ GL017480. Harris, AJ.L, 2009. The pit-craters and pit-crater-filling lavas of Masaya volcano. Bulletin
of Volcanology 71 (5), 541-558. doi: 10.1007/s00445-008-0241-y.

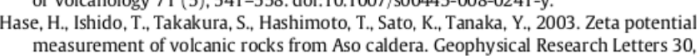
2210. doi: 10.1029/2003GL181899.
. beneath Aso volcano as inferred from self-potential mapping and resistivity struc-
ture. Journal of Volcanology and Geothermal Research $143,25-257$.
ase. J Hashimoto. T, Nishida, Y. Utsugi, M. Inoue, H. Saba, M. 2010. Hydrothermal Hase, H., Hashimoto, T., Nishida, Y., Utsugi, M., Inoue, H., Saba, M., 2010. Hydrothermal
system beneath Usu volcano inferred from self-potential observation and numerisystem beneath Usu volcano inferred from self-potential observation and numen-
cal simulation. Proc. World Geetherm. Congress, 2010, Bali, Indonesia. shido, T., Mizutani, H., 1981. Experimental and theoretical basis of electrokinetic
phenomena in rock-water systems and its applications to geophysics. Journal of

Geophysical Research 86, 1763-1775.
Johnston, M.J.S., Byerlee, J.D., Lockner, D., 2001. Rapid fluid dissuption: a source for self-
potential a a nomalies on volcanoes, Jounnal of Ceophysical Research 106. 4327-4335. Join, J.L., Folio, J.L., Robineau, B., 2005. Aquifers and groundwater within active shield
volcanoes. Evolution of conceptual models in the Piton de la Fournaise volcano.

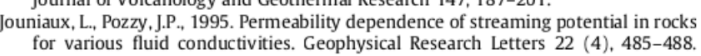
doi: 10.1029/94 GLLO3307.

Naudet, V., Pessel, M., Sailhac, P., 2009. Review of selfpotential methods in hydrogeophysics.
928-936. doi:10.1016/.jcrte.2009.08.008

Legaz, A, Vandemeulebrouck, J., Revil, A., Kemna, A., Hurst, A.W., Reeves, R., 2009. A Case study of resistivity and self-potential signatures of hydrothermal instabilities,
Inferno Crater Lake, Waimangu, New Zealand. Geophysical Research Letters 36 , L12306. doi:10.1029/2009GL037573.

Lénat, J.F, 2007. Retrieving self-potential anomalies in a complex volcanic environ-
ment: an SPPelevation gradient approach. Near Surface Geophysics $5(3) .161-170$ Lewicki, JI Connor, C., St-Amand, K., Stix, J.S.Spinner, W.. 2003. Self-potential, soil CO flux, and temperature on Masaya volc ano, Nicaragua. Geophysical Research Letters

Maciejewski, A.J.H., 1998. Remote measurements of volcanic gases: Applications of
Open-path Fourier transform infra-red spectroscopy (OP-FTR) and Correlation 
electromagnetics and numerical simulation. Journal of Volcanology and Geotherch $166(3-4), 216-232$.

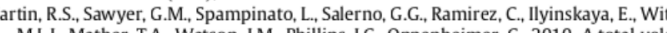
ine inventory for Masay Volcano, Nicaragua. Jounnal of Ceophysical Reseal h 115 Bi, G. W. drothermal systems by self-potential and Multi-scale wavelet tomography. Journj.jvolgeores.2010.02.004.

Mauri, G., Williams-Jones, G., Saracco, G., 2011. MWTmat- application of Multi-scale Wavelet Tomography on potential fied. Conters \& Geosciences Girney, AR, 1956. The Nicaraguan Volcano Mas

37 (1). 83-96 and its Caldera. EOS, Transacetaxian, J-P., 1994. Etude Sismologique et Gravimétrique d'un Volcan Actif: DynaMétaxian, J.P., Lesage, P., Dorel, J., 1997. Permanent tremor of Masaya Volcano, Nicaragua: Wave field analysis and source insley, B.J., Sogade,J., Morgan, F.D., 2007. Three-dimensional source inversion of self-
potential data. Journal of Geophysical Research 112, B02202. doi: 10.1029 , potential data. Journal of Geophysical Research 112, B02202. doi: 10.102
200618004262 .

. Daracco, G, 1997 . Wavelet analysis of potential fields. Inverse Problems 13, 165-178.
Moreau, F., Gilbert, D., Holschneider, M., Saracco, G.. 1999. Identification of sources of potential fields with the continuous wayd
Geophysical Research 104, 5003-5013. adeau, P.A., Williams-Jones, $\mathrm{G}$., 2009. Apparent downwind depletion of volcanic $\mathrm{SO}_{2}$
flux: lessons from Masaya volcano. Nicaragua. Bulletin of Volcanology 71 ,

Pagli, C., Sigmundsson, F., Arnadóttir, T., Einarsson, P., Sturkell, E., 2006. Deflation of the Askja volcanic system: constraints on the deformation source from combined inver-
sion of satellite radar interferograms and GPS measurements. Journal of Volcanology and Geothermal Research 152, 97-108. doi:10.1016/j/jvolgeores 2005.09.014.
Pearson, SCP. 2010, Diffise deg assing and the hydrothermal system at Massy wo no, Nicaragua. Ph.D Thesis, University of South Florida, USA, paper 1736, 147 pp. earson, S.C.P., Connor, C.B.,Sanford, W.E., 2008. Rapid response of a hydrologic system Peterson. FL. 1972. Water development on tropic volcanic islands type example: Hopoldini, E., 1939. Geophysical exploration by spontaneous polarization methods. Mi ribnow, D.F.C., Schütze, C., Hurter, S.J., Fechsig, C., Sass, J.H., 2003. Fluid flow in the resurgent dome of Long Valley Caldera: implications from thermal data and dee

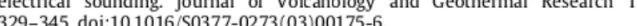
che, O., van Wyk de Vries, B., Druitt, T.H. 2001 . Sub-surface structures and collapse
mechanisms of summitit pit craters. Journal of Volcanology and Geothermal Research 105 (1-2). 1-18.

Rymer, H, van Wyk de Vries, B., Stix, J., Williams-Jones, G., 1998. Pit crater structure
and processes governing persistent activity at Masaya Volcano, Nicaragua Bulletin of Volcanology 59 (5), 345-355.

of SP anomalies caused by subsurface fluid flow. Geophysical Resererse modeling
ofters 28 (9). 1851-1854. Sailhac, P., Galdeano, A., Gilbert, D., Moreau, F., Delor, C., 2000. Identification of sources
of potential fields with the continuous wavelet transform: complex wavelets ant application to aeromagnetic profiles in French Guiana. Journal of Geophysical Research 105 (B8), 19455-19475.

Saracco, G., 1994. Propagation of transient waves through a stratified fluid medium:
wavelet analysis of a nonasymptotic decomposition of the propagator. The Journa of the Anausisa ro honasymplotic dect
Saracco, G., Labazuy, P., Moreau, F., 2004. Localization of self-potential sources in volcano-electric effect with complex continuous wavelet transform and electrical
tomography methods for an active volcano. Geophysical Research Letters 31
L12610. doi: $10.1029 / 2004$ LL L019554.

Saracco, G. Moreau, F., Mathé, P. P.E., Hermitte, D., Michel, J.-M., 2007. Multi-scale tomography of buried magnetic structures: its use in the localization and character-
ization of archeological structures. Geophysical Journal International 171 (1)

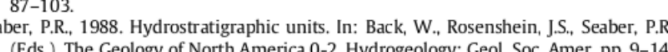
Shaw, A.M. Hilton, D.R., Fischer, T.P., Walker, J.A., Alvarado, G.E., 2003. Contrasting Herelationships in Nicaragua and Costa Rica: insights into C cycling through sub-
duction zones. Earth and Planetary Science Letters 214, 499-513, doi:10.1016 S0012- 821X(03), 00401-1.

Sorey, M.L., Suemnicht, G.A., Sturchio, N.C., Nordquist, G.A., 1991. New evidence on the electrical geophysics, and age determinations of hot-spring deposits Journal of

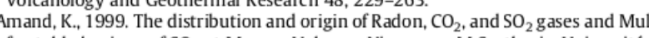
Montreal, Canada, $270 \mathrm{pp}$.
Stoiber, R.E., Williams, S.N., Huebert, B.J., Sato, M., Matsuo, S., King. C., 1986 . Sulfur and halogen gases at Masaya Caldera complex, Nicaragua; total flux and variations
with time. Journal of Geophysical Research 91, 12215-12231. doi:10.1029 JB091iB12p12215. Todesco, T., Rinaldi, A.P., Bonafede, M., 2010. Modeling of unrest signals in heteroge-
neous hydrothermal systems. Journal of Geophysical Research 115, B09213 neous hydrothermal systems. Journal of Geophysical Research 115, B09213.
doi:10.1029/2010|j007474. Walker, JA... Williams, S.N., 1986. Shallow magmatic processes beneath Masaya Calder Complex, Nicaragua. Eos, Transactions, American Geophysical Union 67 (16), 411.
Walker, JA., Williams, S.N. Kalamarides, R.L., Feigenson, M.D. 1993. Shallow openalker, J.A. Williams. S.N. Kalamarides, R.I., Feigenson, M.D. 1993. Shallow open-
system evolution of basaltic magma beneath a subduction zone volcano: the Macaya Caldera Complex, Nicaragua Journal of Volcanology and Geothermal Research $56,379-400$.
dén, B., Majdi, $\mathrm{H}, 2001$. Soil $\mathrm{CO}_{2}$ efflux and root respiration at three sites in a mixed

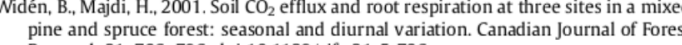
pine and spruce forest: seasonal and diurnal variation. Canadian Jork
Research 31, 786-796. doi:10.1139/.jf-31-5-786.

211-214. doi: 10.1130/0091-7613(1983) 11. Williams, S.N. 1983b. Geology and eruptive mechanisms of Masaya Caldera complex, Nicaragua, PhD Thesis, Darthmouth College, Hanover, New Hampshire, USA, $169 \mathrm{pp}$.
Williams-Jones, G., Stix, J., Heiligmann, M., Charland, A, Sherwood Lollar, B., Garrón V.G... Barquero, J., Fernandez, E., 2000. A model of diffuse degassing at three Williams-Jones, G., Rymer, H., Rothery, D.A., 2003. Gravity changes and passive $\mathrm{SO}_{2}$ degassing at the Masaya caldera complex, Nicaragua. Journal of Volcanology an Geohermal Research 123 (1-2), 136-160

logical insights of self-potential anomalies on volcanoes. Surveys in Geophysics 24 (4), 291-338.
lotnicki, J, Michel, S., Annen, C, 1994. Self-potential anomalies and convective system on La-Fournaise volcano (Réunion Island, France). Comptes Rendus de l'Académ trnicki,J.., Boudon, G.. Viodé, J.P., Delarue, J.F., Mille, A., Bruère, E., 1998. Hydrotherma circulation beneath Mount Pelée inferred by self-potential surveying. Structural
and tectonic implications. Journal of Volcanology and Geothermal Research 84

otnicki, ,., sasai, Y., Toutain, J.P., Villacorte, E., Harada, M., PHIVOLCS team, Yvetot, P. to investien Benar, A., 2009. Electromagnetic and geochemical methods applied and Miyake-jima (Japan) volcanoes. Physics and Chemistry of the Earth 34 